\title{
Diversity and Antimicrobial Activity of Vietnamese Sponge-Associated Bacteria
}

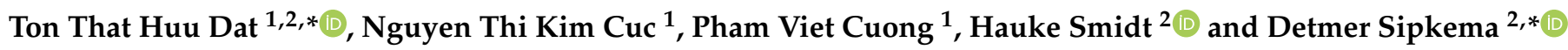 \\ 1 Mientrung Institute for Scientific Research, Vietnam Academy of Science and Technology, \\ 321 Huynh Thuc Khang, Hue City, Thua Thien Hue 531600, Vietnam; kimcuc@imbc.vast.vn (N.T.K.C.); \\ pvcuong@misr.vast.vn (P.V.C.) \\ 2 Laboratory of Microbiology, Wageningen University \& Research, Stippeneng 4, 6708 WE Wageningen, \\ The Netherlands; hauke.smidt@wur.nl \\ * Correspondence: huudat.ton@wur.nl (T.T.H.D.); detmer.sipkema@wur.nl (D.S.); \\ Tel.: +84-94-949-2778 (T.T.H.D.); +31-317-483-113 (D.S.)
}

Citation: Dat, T.T.H.; Cuc, N.T.K.; Cuong, P.V.; Smidt, H.; Sipkema, D. Diversity and Antimicrobial Activity of Vietnamese Sponge-Associated Bacteria. Mar. Drugs 2021, 19, 353 https://doi.org/10.3390/md19070353

Academic Editors: Vida Šimat, Ipek Kurtboke and Peter Proksch

Received: 29 December 2020

Accepted: 18 June 2021

Published: 22 June 2021

Publisher's Note: MDPI stays neutral with regard to jurisdictional claims in published maps and institutional affiliations.

\begin{abstract}
This study aimed to assess the diversity and antimicrobial activity of cultivable bacteria associated with Vietnamese sponges. In total, 460 bacterial isolates were obtained from 18 marine sponges. Of these, $58.3 \%$ belonged to Proteobacteria, $16.5 \%$ to Actinobacteria, $18.0 \%$ to Firmicutes, and $7.2 \%$ to Bacteroidetes. At the genus level, isolated strains belonged to 55 genera, of which several genera, such as Bacillus, Pseudovibrio, Ruegeria, Vibrio, and Streptomyces, were the most predominant. Culture media influenced the cultivable bacterial composition, whereas, from different sponge species, similar cultivable bacteria were recovered. Interestingly, there was little overlap of bacterial composition associated with sponges when the taxa isolated were compared to cultivation-independent data. Subsequent antimicrobial assays showed that 90 isolated strains exhibited antimicrobial activity against at least one of seven indicator microorganisms. From the culture broth of the isolated strain with the strongest activity (Bacillus sp. M1_CRV_171), four secondary metabolites were isolated and identified, including cyclo(L-Pro-L-Tyr) (1), macrolactin A (2), macrolactin H (3), and 15,17-epoxy-16hydroxy macrolactin A (4). Of these, compounds 2-4 exhibited antimicrobial activity against a broad spectrum of reference microorganisms.
\end{abstract}

Keywords: antimicrobial activity; cultivable bacteria; secondary metabolites; sponge-associated bacteria

\section{Introduction}

Antimicrobial resistance decreases the possibilities for prevention and treatment of infectious diseases caused by viruses, bacteria, parasites, and fungi. Factors listed as causes for the rising prevalence of antibiotic resistance include over-prescription of antibiotics both in hospitals and agriculture, poor infection control in hospitals and clinics, lack of hygiene, and poor sanitation [1-5]. Thus, antibiotic resistance has considerable social and economic impact by the increase of morbidity and mortality of infectious diseases. Currently, it is estimated that approximately 700,000 people die every year from drug-resistant infections. By 2050, antibiotic resistance may attribute to 10 million deaths worldwide each year and trigger an economic loss of up to 100 trillion US dollars [6]. While antibiotic resistance increases, only a limited number of new antibiotics have been discovered and approved for medical treatment [7]. Therefore, increasing efforts towards discovery and exploitation of novel antimicrobial compounds are urgently needed.

Modifications of existing drugs are often not effective enough to overcome the mutation rate of microbial pathogens and do not lead to the introduction of new classes of antimicrobial compounds [8]. In addition, chemical synthesis and semi-synthesis approaches of new antimicrobial compounds and their analogues are hindered by the complexity of the molecules and low yield $[9,10]$. Therefore, the discovery of novel antimicrobial compounds from the biosphere remains an important avenue for finding our future antibiotics. 
The terrestrial environment has been the main source of new antibiotics in recent decades. However, re-discovery of known compounds has limited the development of new drugs from the terrestrial environment for treating infectious diseases [7]. The marine environment encompasses several of the richest ecosystems on Earth, with an extreme diversity of life forms. However, its bioactive compounds have been largely unexplored [11-13]. Of marine organisms, sponges (phylum Porifera) are considered the most promising source of bioactive natural products and contribute about $30 \%$ of the known marine natural products [14,15]. Furthermore, sponge-derived compounds exhibit a wide spectrum of biological properties, including antimicrobial, anticancer, antiinflammatory, immunosuppressive, and neurosuppressive activity [14-17]. However, the low concentration of sponge-derived compounds in their tissues has led to issues with supply and halted preclinical and clinical studies of many promising therapeutic drug candidates [18].

To date, of many sponge-derived secondary metabolites, the true origin is unknown. The secondary metabolites could be produced by the sponges, by their microbial symbionts, or by the cooperation between sponges and symbionts [19]. Interestingly, several studies have highlighted that many bioactive compounds from sponges might be of bacterial origin due to the structural similarity of the molecules to compounds found in terrestrial microorganisms [20-22]. For example, it is now known that polybrominated biphenyl ether antibiotics isolated from the sponge Dysidea herbacea are actually produced by the endosymbiotic cyanobacterium Oscillatoria spongeliae [23]. The antifungal peptide theopalauamide isolated from the marine sponge Theonella swinhoei has been found to be contained in a $\delta$-proteobacterial symbiont [24]. Furthermore, recent studies have confirmed that sponge-associated microorganisms are a valuable source of antimicrobial compounds with potent biological activity and diverse structural features, which make these microbial communities promising sources of novel antimicrobials [22,25-27]. Thus, obtaining the sponge-associated bacterial producers of these compounds as pure cultures presents a way to overcome the supply issue.

A previous study based on cultivation-independent methods showed a high diversity of the prokaryotic communities associated with Vietnamese sponges [28]. To explore the antimicrobial activity from sponge-associated bacteria, in this study, we aimed to isolate bacteria and screen the antimicrobial activity from 18 Vietnamese sponge species. The strain (Bacillus sp. M1_CRV_171) with the highest antimicrobial activity was then subjected to isolation and purification of antimicrobial compounds.

\section{Results}

\subsection{Diversity of Sponge-Associated Cultivable Bacteria}

In total, agar plates with seven different media yielded 473 bacterial colonies from 18 sponge species (Table S1). Of these, 460 bacterial colonies were regrown and identified by their $16 \mathrm{~S}$ rRNA gene sequences. The isolated strains included four phyla: Proteobacteria $(\alpha-, \gamma$ - and $\beta$-proteobacteria), Actinobacteria, Firmicutes, and Bacteroidetes (Figure 1A). Among them, the phylum Proteobacteria was the most predominant (58.3\% of the isolated strains), followed by Firmicutes (18.0\%) and Actinobacteria (16.5\%), whereas the phylum Bacteroidetes represented $7.2 \%$ of the isolated strains. At the genus level, 55 genera were represented, of which the genera Bacillus, Pseudovibrio, Ruegeria, Vibrio, and Streptomyces were the most predominant, each accounting for more than $5 \%$ of all isolated strains (Figures 1B and 2). The number of bacterial genera recovered from sponges ranged from 15 to 21 . The composition of cultivable bacteria from different sponges was relatively similar at the genus level (Figure 2). 

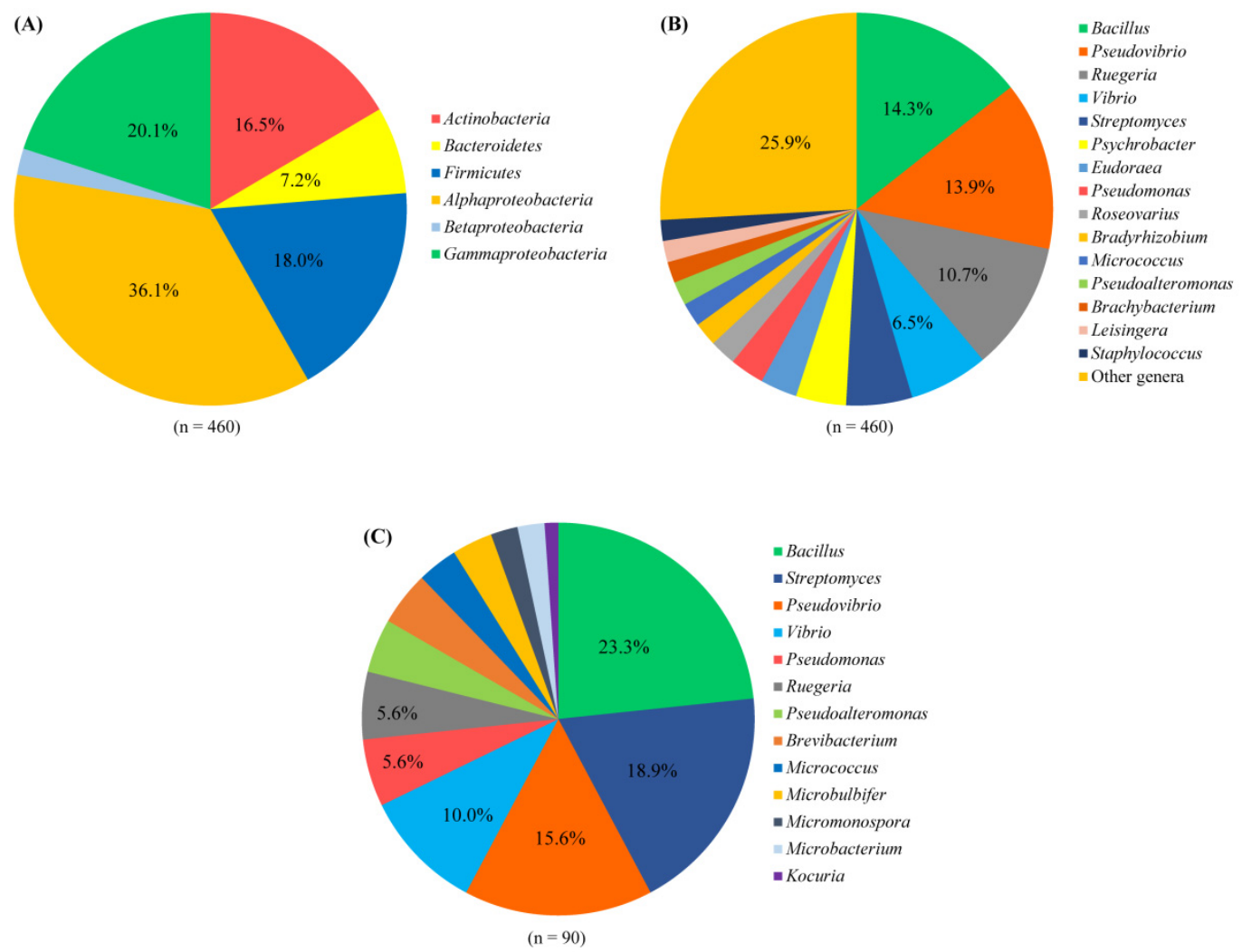

Figure 1. Composition of cultivable bacteria associated with sponges at the phylum level (at the class level for the phylum Proteobacteria) (A) and the genus level (B). Composition of bacteria with antimicrobial activity associated with sponges at the genus level $(\mathbf{C})$.

The culture media significantly affected the cultivable bacteria ( $p$-values of 0.21 (Betadisper) and $<0.001$ (Adonis)) (Table S2). Although the most abundant genera Bacillus, Pseudovibrio, Ruegeria, Vibrio, and Streptomyces were isolated on all cultivation media, several genera were only isolated from nutrient-poor media, such as Arthrobacter, Curtobacterium, Nonlabens, Tenacibaculum, Exiguobacterium, Anderseniella, Pseudoruegeria, Thalassobius, and Alcanivorax (Figure 3). None of the isolated strains represented new species as, based on their 16S ribosomal RNA (rRNA) gene sequence, they were all 99-100\% similar to known strains (Table S5). The nutrient-rich media resulted in higher numbers of colonies and genera than nutrient-poor media (e.g., OLIGO, SWA) (Table S1). M1 medium yielded the highest number of genera (38), followed by MA medium (35 genera), R2A (33 genera), SCA (30 genera), AIA (27 genera), and OLIGO (23 genera), and the lowest number of genera was observed with SWA, on which 17 genera were recovered (Figure 3). In addition, nutrient-rich media had significantly higher richness, Shannon diversity, and Inverse Simpson diversity, while nutrient-poor media (i.e., OLIGO, SWA) exhibited higher evenness (Tables S3 and S4). The higher alpha diversity indices for rich media may be partially explained by the higher number of colonies obtained from those media (Table S1).

The 16S rRNA gene sequences from the isolated strains were compared to sequences that were generated by direct Illumina MiSeq amplicon sequencing analysis of the same sponge samples [28]. Six OTUs out of 921 OTUs detected by MiSeq sequences were also found by cultivation; however, their abundance was distinct for the two methods (Figure 4). For example, OTU909 (Bacillus), OTU337 (Pseudovibrio), OTU541 (Ruegeria), and OTU710 (Pseudoalteromonas) were cultivated from all sponge species; however, these OTUs were not detected or detected at very low relative abundance from the same sponge species by MiSeq analysis. 


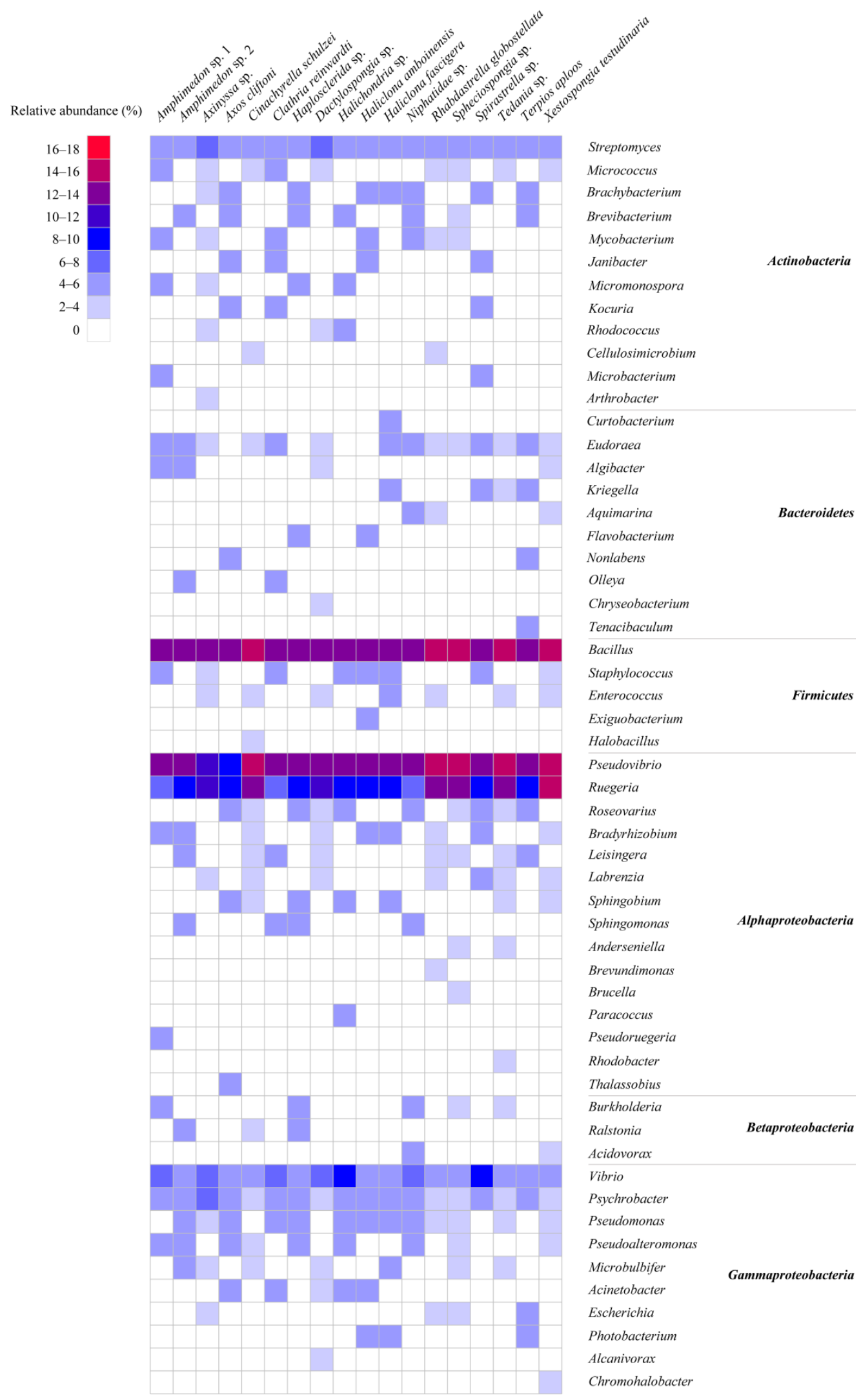

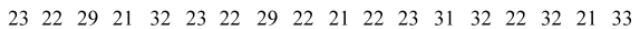
Number of isolates

Figure 2. Heatmap of the composition and relative abundance of cultivable bacteria isolated from different sponge species at the genus level. 


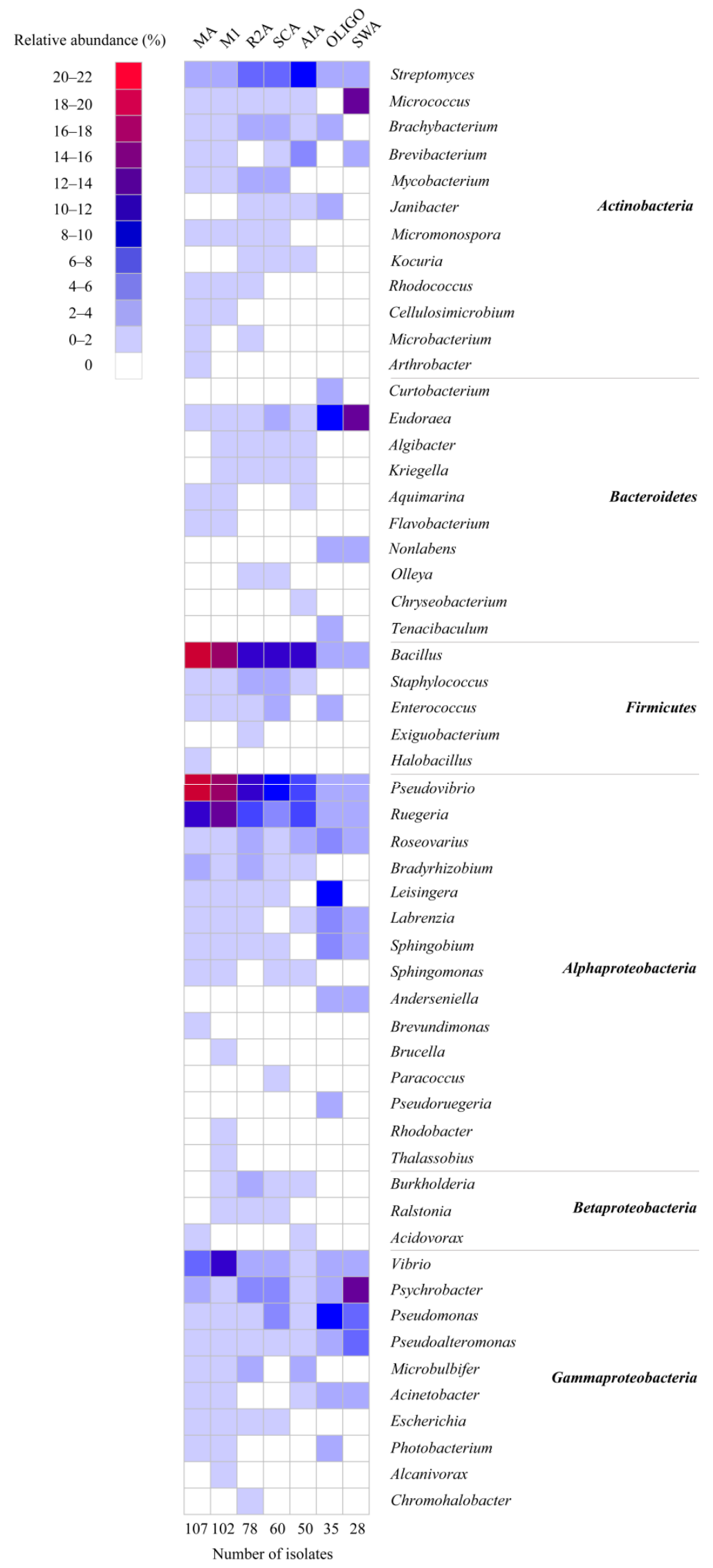

Figure 3. Heat map of the composition and relative abundance of cultivable bacteria isolated from different culture media at the genus level. 


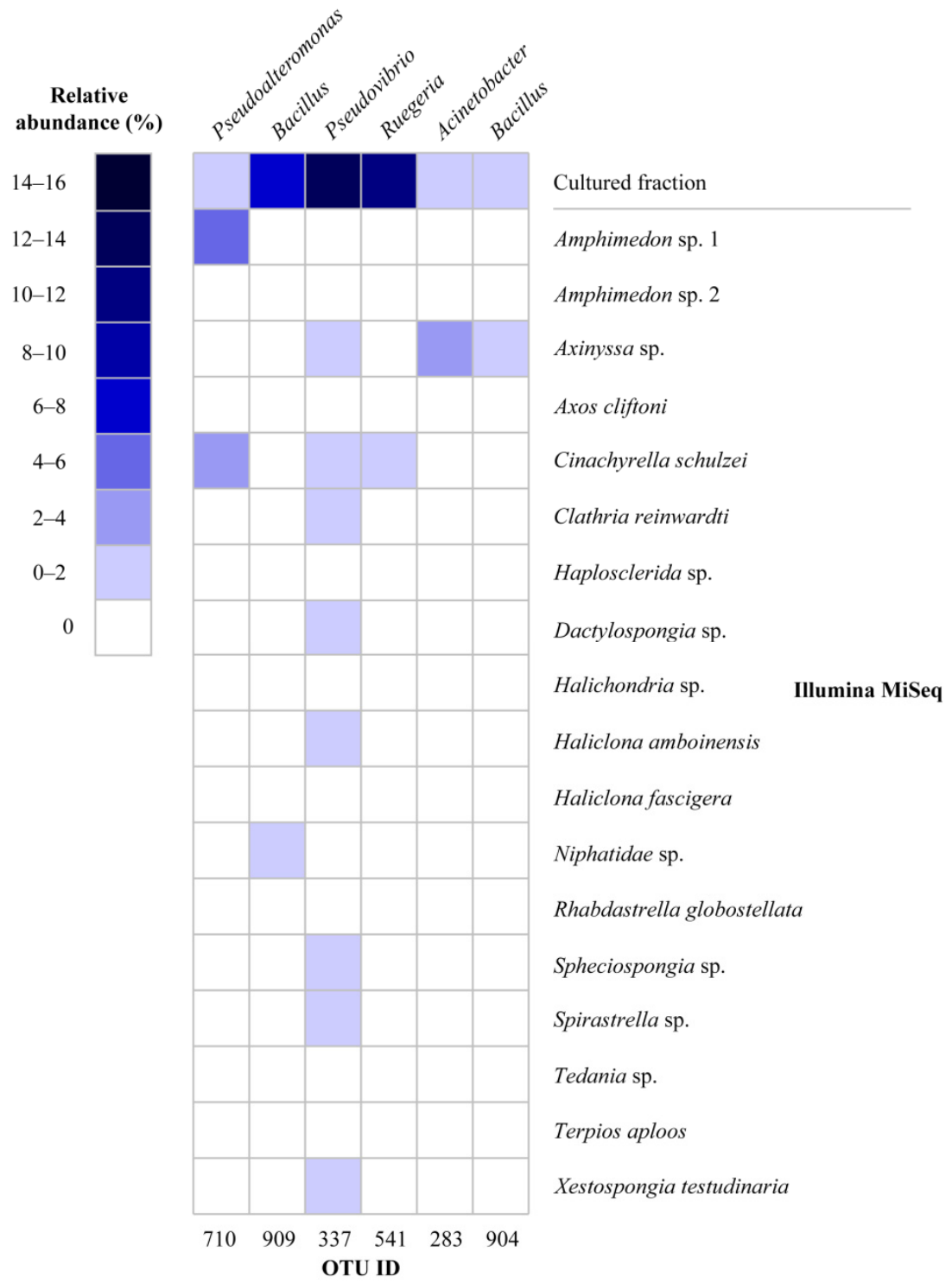

Figure 4. Heat map of relative abundance of shared OTUs recovered by cultivation and cultivationindependent approaches (MiSeq). The relative abundance of OTUs in the cultivable fraction was calculated for total sequences for all sponge species, whereas the relative abundance of OTUs in Illumina MiSeq data was calculated for each sponge species.

\subsection{Antimicrobial Activity of Isolated Strains}

Cell-free supernatants from cultures of all isolated strains $(n=460)$ were screened for their antimicrobial activity against seven indicator microorganisms: Escherichia coli ATCC 25922, Pseudomonas aeruginosa ATCC 25923, Bacillus subtilis ATCC 27212, Staphylococcus aureus ATCC 12222, Candida albicans ATCC 7754, Salmonella enterica ATCC 13076, and Enterococcus faecalis ATCC 29212. The cell-free culture supernatants of 90 isolated strains (nearly 20\%) showed antimicrobial activity against one or more of the tested indicator microorganisms (Table 1). Among them, the cell-free culture supernatants of 57 isolated strains exhibited activity against one indicator strain, while 21 isolated strains exhibited activity against 2 indicator strains, 8 isolated strains exhibited activity against 3 indicator strains, 3 isolated strains exhibited activity against 4 indicator strains, and 1 isolated strain exhibited activity against 5 tested indicator strains. It was observed that the cell-free culture supernatants showed more antimicrobial activity towards Gram-positive bacteria (21 isolated strains against $S$. aureus, 26 isolated strains against E. faecalis, and 27 isolated strains against $B$. subtilis) than Gram-negative bacteria (16 isolated strains against 
P. aeruginosa, 17 isolated strains against $S$. enterica, and 20 isolated strains against $E$. coli), whereas the number of isolated strains exhibiting activity against yeast was the lowest (15 isolated strains). The identification of the active isolated strains revealed that they belonged to 13 genera, with Bacillus, Streptomyces, and Pseudovibrio being predominant with $23.3 \%, 18.9 \%$, and $15.6 \%$, respectively (Figure 1C).

Table 1. Antimicrobial activity of isolated bacterial strains.

\begin{tabular}{|c|c|c|c|c|c|c|c|c|}
\hline \multirow{3}{*}{ Isolated Strains } & \multirow{3}{*}{ Genus } & \multicolumn{7}{|c|}{ Inhibition Zone Diameter (mm) } \\
\hline & & \multicolumn{3}{|c|}{ Gram-Negative } & \multicolumn{3}{|c|}{ Gram-Positive } & \multirow{2}{*}{$\begin{array}{c}\text { Yeast } \\
\text { CA }\end{array}$} \\
\hline & & SE & EC & PA & SA & EF & BS & \\
\hline MA_AMC_32 & Bacillus & - & - & - & $10 \pm 2$ & - & - & - \\
\hline MA_AMQ_66 & Bacillus & - & $7 \pm 2$ & - & - & - & $8 \pm 3$ & - \\
\hline MA_AXT_69 & Bacillus & $7 \pm 2$ & - & - & - & - & - & - \\
\hline MA_AXT_70 & Bacillus & $5 \pm 2$ & - & $8 \pm 3$ & $6 \pm 3$ & - & $8 \pm 3$ & - \\
\hline MA_AXC_75 & Bacillus & - & $7 \pm 2$ & - & - & - & - & - \\
\hline MA_CIS_78 & Bacillus & - & - & - & - & - & - & $6 \pm 2$ \\
\hline M1_CRV_171 & Bacillus & - & $5 \pm 2$ & $8 \pm 2$ & $7 \pm 3$ & $10 \pm 3$ & - & $6 \pm 2$ \\
\hline M1_DAS_199 & Bacillus & - & - & $12 \pm 3$ & - & - & - & - \\
\hline M1_HAA_234 & Bacillus & - & - & - & - & $5 \pm 1$ & $11 \pm 3$ & $7 \pm 2$ \\
\hline M1_HAA_246 & Bacillus & - & - & - & $6 \pm 2$ & - & - & - \\
\hline M1_NIS_274 & Bacillus & $5 \pm 2$ & - & - & - & - & - & - \\
\hline R2A_NIS_276 & Bacillus & - & - & - & - & - & $12 \pm 3$ & - \\
\hline R2A_RHG_312 & Bacillus & - & - & - & $5 \pm 2$ & - & - & - \\
\hline R2A_SPV_326 & Bacillus & - & - & $7 \pm 2$ & - & $5 \pm 2$ & $7 \pm 2$ & - \\
\hline R2A_SPV_338 & Bacillus & - & $4 \pm 1$ & - & - & $3 \pm 1$ & - & $6 \pm 2$ \\
\hline SCA_SPS_344 & Bacillus & - & - & - & - & - & $4 \pm 1$ & - \\
\hline SCA_TES_347 & Bacillus & - & - & - & - & - & - & $4 \pm 1$ \\
\hline AIA_TEA_438 & Bacillus & - & - & - & - & $4 \pm 1$ & - & - \\
\hline AIA_XES_454 & Bacillus & - & - & $15 \pm 3$ & - & - & - & - \\
\hline AIA_XES_458 & Bacillus & $12 \pm 3$ & - & - & - & - & - & $10 \pm 3$ \\
\hline M1_HAF_272 & Bacillus & - & $10 \pm 3$ & - & - & - & $8 \pm 3$ & - \\
\hline AIA_SPV_375 & Brevibacterium & - & - & - & - & $12 \pm 3$ & - & - \\
\hline AIA_HAS_264 & Brevibacterium & - & - & - & - & - & $4 \pm 1$ & - \\
\hline M1_AXC_175 & Brevibacterium & - & - & - & - & $6 \pm 2$ & $10 \pm 3$ & - \\
\hline MA_AMQ_34 & Brevibacterium & - & $8 \pm 3$ & - & - & - & $9 \pm 2$ & - \\
\hline R2A_AXC_194 & Kocuria & $10 \pm 4$ & - & - & $14 \pm 4$ & - & - & $7 \pm 2$ \\
\hline MA_AMC_87 & Microbacterium & - & - & - & $6 \pm 2$ & - & - & - \\
\hline R2Ā_SPS_90 & Microbacterium & - & - & - & $4 \pm 1$ & - & - & - \\
\hline M1_AXT_2 & Microbulbifer & - & - & - & $5 \pm 1$ & - & - & - \\
\hline R2A_DAS_4 & Microbulbifer & - & - & $3 \pm 1$ & - & - & - & - \\
\hline AIA_TES_7 & Microbulbifer & - & $12 \pm 4$ & - & - & - & - & - \\
\hline R2A_CIS_91 & Micrococcus & - & - & - & - & - & - & $9 \pm 2$ \\
\hline SCA_CLR_217 & Micrococcus & $8 \pm 3$ & - & - & - & - & - & - \\
\hline M1_AXT_88 & Micrococcus & $11 \pm 3$ & - & - & - & - & - & - \\
\hline R2A_CRV_10 & Micromonospora & - & - & $13 \pm 3$ & - & - & $8 \pm 2$ & - \\
\hline SCA_HAS_11 & Micromonospora & - & - & - & $6 \pm 2$ & $6 \pm 2$ & - & $4 \pm 1$ \\
\hline M1_AXC_17 & Pseudoalteromonas & - & - & - & - & $8 \pm 3$ & - & - \\
\hline MA_AMC_15 & Pseudoalteromonas & $6 \pm 2$ & - & - & $10 \pm 4$ & $8 \pm 4$ & - & $4 \pm 2$ \\
\hline R2A_CIS_18 & Pseudoalteromonas & - & - & - & - & - & $7 \pm 2$ & - \\
\hline SCA_CRV_19 & Pseudoalteromonas & - & - & - & - & $6 \pm 1$ & - & - \\
\hline MA_AMQ_98 & Pseudomonas & - & - & $6 \pm 2$ & - & - & - & $4 \pm 1$ \\
\hline M1_AXT_131 & Pseudomonas & - & $12 \pm 4$ & - & - & - & - & - \\
\hline R2A_AXC_259 & Pseudomonas & - & - & - & - & - & $6 \pm 2$ & - \\
\hline SCA_CLR_279 & Pseudomonas & - & - & $9 \pm 3$ & - & - & - & - \\
\hline AIA_HAA_313 & Pseudomonas & - & $11 \pm 4$ & - & - & $9 \pm 2$ & $14 \pm 4$ & - \\
\hline MA_AMC_93 & Pseudovibrio & - & - & - & $3 \pm 1$ & - & - & - \\
\hline MA_AMC_33 & Pseudovibrio & - & - & $6 \pm 3$ & - & - & - & - \\
\hline MA_AMQ_100 & Pseudovibrio & - & - & - & - & $12 \pm 4$ & - & - \\
\hline MA_AXT_177 & Pseudovibrio & $13 \pm 4$ & - & - & $10 \pm 3$ & - & - & - \\
\hline
\end{tabular}


Table 1. Cont.

\begin{tabular}{|c|c|c|c|c|c|c|c|c|}
\hline \multirow{3}{*}{ Isolated Strains } & \multirow{3}{*}{ Genus } & \multicolumn{7}{|c|}{ Inhibition Zone Diameter (mm) } \\
\hline & & \multicolumn{3}{|c|}{ Gram-Negative } & \multicolumn{3}{|c|}{ Gram-Positive } & \multirow{2}{*}{$\begin{array}{c}\text { Yeast } \\
\text { CA }\end{array}$} \\
\hline & & SE & EC & PA & SA & EF & BS & \\
\hline MA_AXC_181 & Pseudovibrio & $13 \pm 4$ & - & - & - & - & - & - \\
\hline MA_CIS_184 & Pseudovibrio & $11 \pm 4$ & - & - & - & $8 \pm 2$ & $10 \pm 3$ & - \\
\hline MA_CIS_186 & Pseudovibrio & - & - & $5 \pm 1$ & - & - & - & - \\
\hline MA_CIS_195 & Pseudovibrio & - & - & - & - & - & $7 \pm 1$ & - \\
\hline MA_CRV_231 & Pseudovibrio & - & $8 \pm 3$ & - & - & - & - & - \\
\hline M1_DAS_236 & Pseudovibrio & - & $13 \pm 3$ & - & - & $7 \pm 2$ & $10 \pm 3$ & - \\
\hline M1_HAA_265 & Pseudovibrio & - & - & - & - & - & - & $5 \pm 1$ \\
\hline R2A_RHG_301 & Pseudovibrio & - & - & $6 \pm 2$ & - & - & - & - \\
\hline SCA_TES_374 & Pseudovibrio & $8 \pm 2$ & - & - & $14 \pm 4$ & - & - & - \\
\hline AIA_TEA_401 & Pseudovibrio & - & $15 \pm 4$ & - & - & - & - & - \\
\hline MA_AMQ_136 & Ruegeria & - & - & $6 \pm 2$ & - & - & - & - \\
\hline MA_AXT_139 & Ruegeria & $4 \pm 1$ & - & - & $7 \pm 2$ & $7 \pm 2$ & $13 \pm 4$ & - \\
\hline MA_CIS_145 & Ruegeria & - & $13 \pm 4$ & - & - & $7 \pm 2$ & - & - \\
\hline M1_DAS_153 & Ruegeria & $3 \pm 1$ & - & - & - & - & - & - \\
\hline R2A_SPV_381 & Ruegeria & - & $6 \pm 2$ & - & - & - & - & - \\
\hline MA_AMC_38 & Streptomyces & - & - & $3 \pm 1$ & - & $8 \pm 4$ & - & - \\
\hline MA_AMQ_39 & Streptomyces & $7 \pm 2$ & - & - & $5 \pm 2$ & - & - & - \\
\hline M1_AXT_41 & Streptomyces & - & $13 \pm 3$ & - & - & - & - & - \\
\hline M1_CIS_51 & Streptomyces & - & - & - & $6 \pm 2$ & - & $10 \pm 3$ & - \\
\hline R2A_CLR_53 & Streptomyces & - & $4 \pm 1$ & - & $4 \pm 2$ & - & - & - \\
\hline R2A_DAS_58 & Streptomyces & - & - & - & - & - & $8 \pm 3$ & - \\
\hline R2A_HAS_60 & Streptomyces & - & - & - & - & $7 \pm 2$ & - & - \\
\hline SCA_HAF_63 & Streptomyces & - & $9 \pm 3$ & - & - & - & - & - \\
\hline SCA_RHG_65 & Streptomyces & - & - & - & $7 \pm 2$ & - & - & - \\
\hline AIA_SPV_83 & Streptomyces & - & $6 \pm 2$ & - & - & - & - & - \\
\hline AIA_SPS_85 & Streptomyces & - & - & - & - & - & $4 \pm 2$ & - \\
\hline AIA_TEA_127 & Streptomyces & - & - & - & - & $5 \pm 2$ & - & - \\
\hline AIA_TES_126 & Streptomyces & - & - & - & - & - & $14 \pm 4$ & - \\
\hline AIA_TES_125 & Streptomyces & - & $4 \pm 1$ & - & $7 \pm 2$ & - & - & - \\
\hline OLIGO_XES_128 & Streptomyces & $3 \pm 1$ & - & - & - & - & - & - \\
\hline SWA_X̄ES_129 & Streptomyces & - & $8 \pm 3$ & - & - & - & $10 \pm 3$ & - \\
\hline AIA_SPV_84 & Streptomyces & - & - & - & - & - & $10 \pm 3$ & $7 \pm 2$ \\
\hline MA_AMC_44 & Vibrio & - & - & - & - & $5 \pm 3$ & - & $6 \pm 2$ \\
\hline R2A_SPS_117 & Vibrio & - & - & - & - & - & $8 \pm 3$ & - \\
\hline MA_AMQ_46 & Vibrio & - & - & - & $10 \pm 3$ & - & - & - \\
\hline AIA_TEA_122 & Vibrio & - & - & - & - & $4 \pm 2$ & - & - \\
\hline M1_RHG_114 & Vibrio & - & - & - & - & - & - & $4 \pm 1$ \\
\hline M1_HAA_109 & Vibrio & - & - & $12 \pm 3$ & - & - & - & - \\
\hline MA_AIS_55 & Vibrio & - & - & - & - & $5 \pm 1$ & - & - \\
\hline SCA_TES_120 & Vibrio & $11 \pm 3$ & - & - & - & $17 \pm 3$ & - & - \\
\hline M1_CLR_86 & Vibrio & - & - & $13 \pm 4$ & - & - & - & - \\
\hline Ampicillin & & $18 \pm 3$ & $20 \pm 4$ & - & $25 \pm 4$ & $21 \pm 3$ & $23 \pm 3$ & na \\
\hline Kanamycin & & $12 \pm 2$ & $17 \pm 3$ & - & $19 \pm 3$ & $18 \pm 2$ & $19 \pm 2$ & na \\
\hline Tetracycline & & $10 \pm 2$ & $19 \pm 3$ & - & $22 \pm 3$ & $15 \pm 2$ & $21 \pm 3$ & na \\
\hline Miconazole & & na & na & na & na & na & na & $17 \pm 2$ \\
\hline
\end{tabular}

SE-Salmonella enterica ATCC 13076; EC-Escherichia coli ATCC 25922; PA-Pseudomonas aeruginosa ATCC 27853; SA-Staphylococcus aureus ATCC 25923; EF-Enterococcus faecalis ATCC 29212; BS—Bacillus subtilis ATCC 6633; CA—Candida albicans ATCC 10231; “-": no inhibition; na: not applicable; values in table: mean \pm SD of triplicate.

\subsection{Isolation and Identification of the Compounds Produced by Bacillus sp. M1_CRV_171}

Well diffusion assays revealed that Bacillus sp. M1_CRV_171 was the only isolated strain to inhibit five reference strains, including Gram-negative bacteria, Gram-positive bacteria, and yeast. Furthermore, this isolated strain was also found in the same sponge by the cultivation-independent method [28], as the 16S rRNA gene sequence of this isolated strain was $100 \%$ identical with a bacterial OTU recovered from sponge tissue. Therefore, 
this isolated strain was subjected to isolation of secondary metabolites. Isolation and purification of ethyl acetate extracts from the culture broth of Bacillus sp. M1_CRV_171 led to the isolation of four compounds 1-4 (Figure 5). The structures of these compounds were elucidated by the examination of their ESI-MS and NMR $\left({ }^{1} \mathrm{H}\right.$ NMR, ${ }^{13} \mathrm{C}$ NMR, HMBC, HSQC) spectra (Figures S1-S20) and comparison with reported data. The compounds were identified as cyclo(L-Pro-L-Tyr) (1) [29], macrolactin A (2) [30,31], macrolactin H (3) [32], and 15,17-epoxy-16-hydroxy macrolactin A (4) [33].<smiles>O=C1N[C@@H](Cc2ccc(O)cc2)C(=O)N2CCC[C@H]12</smiles><smiles>C/C=C\C=C/[C@@H](O)C/C=C/C=C\C(=O)O[C@H](C)CCC/C=C/[C@H](O)C[C@@H](O)/C=C\C</smiles><smiles>CC1C=CC=CCCC[C@@H](C)OC(=O)C=CC=CC[C@@H](O)CC(O)CC=CC=C1</smiles>

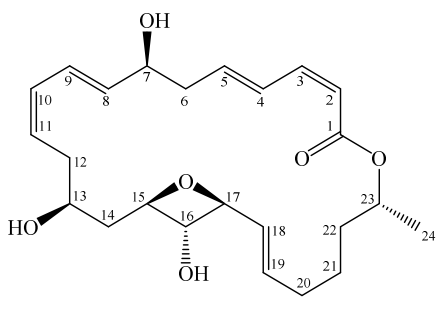

15,17-epoxy-16-hydroxy macrolactin A (4)

Figure 5. Chemical structures of isolated compounds (1-4).

\subsection{Antimicrobial Activity of the Isolated Secondary Metabolites}

The four compounds isolated from the strain Bacillus sp. M1_CRV_171 were evaluated for their antimicrobial activity against a broad spectrum of microorganisms (Table 2). Compound 1 was inactive against most of the reference strains, except for S. aureus, Vibrio parahaemolyticus, Fusarium oxisporum, and Ralstonia solani, with minimum inhibitory concentrations (MICs) $>256 \mu \mathrm{g} / \mathrm{mL}$. Compounds 2-4 exhibited antimicrobial activity against a wide spectrum of reference strains. Compound 2 exhibited antimicrobial activity against P. aeruginosa, S. aureus, and Rhodococcus sp., with MICs of 8,16 , and $32 \mu \mathrm{g} / \mathrm{mL}$, respectively. Notably, antimicrobial activity against $P$. aeruginosa of compound 2 was comparable to the positive controls tetracycline (MIC > $64 \mu \mathrm{g} / \mathrm{mL}$ ), kanamycin (MIC > $256 \mu \mathrm{g} / \mathrm{mL}$ ), and ampicillin (MIC > $256 \mu \mathrm{g} / \mathrm{mL}$ ). Furthermore, compound 2 exhibited activity against a wide spectrum of tested microorganisms, with MICs ranging from 64 to $>256 \mu \mathrm{g} / \mathrm{mL}$, while it was inactive against S. enterica, E. faecalis, Vibrio vulnificus, and Vibrio alginolyticus. Compound 3 showed antimicrobial activity against E. coli and $S$. aureus, with MIC values of $16 \mu \mathrm{g} / \mathrm{mL}$ and $32 \mu \mathrm{g} / \mathrm{mL}$, respectively, which was comparable to the positive controls (ampicillin, kanamycin, and tetracycline), with MIC values ranging from 4 to $16 \mu \mathrm{g} / \mathrm{mL}$. Compound 3 also exhibited antimicrobial activity against other tested microorganisms, with MICs ranging from 64 to $>256 \mu \mathrm{g} / \mathrm{mL}$. For compound 4, the strongest activity was found against $E$. coli, with a MIC value of $32 \mu \mathrm{g} / \mathrm{mL}$. For other tested microorganisms, compound 4 showed antimicrobial activity with MICs $\geq 64 \mu \mathrm{g} / \mathrm{mL}$. 
Table 2. Antimicrobial activity of the isolated compounds 1,2,3, and 4 .

\begin{tabular}{|c|c|c|c|c|c|c|c|c|}
\hline \multirow{2}{*}{ Reference Microorganisms } & \multicolumn{8}{|c|}{ MIC ( $\mu \mathrm{g} / \mathrm{mL})$} \\
\hline & 1 & 2 & 3 & 4 & Amp & Kan & Tet & Mic \\
\hline \multicolumn{9}{|c|}{ Gram negative bacteria } \\
\hline E. coli ATCC 25922 & - & 64 & 16 & 32 & 8 & 16 & 4 & na \\
\hline S. enterica ATCC 13076 & - & - & $>256$ & $>256$ & 16 & 64 & 32 & na \\
\hline P. aeruginosa ATCC 27853 & - & 8 & 64 & 64 & $>256$ & $>256$ & 64 & na \\
\hline P. putida MISR 71218 & - & 128 & 128 & 128 & $>256$ & 64 & 64 & na \\
\hline V. parahaemolyticus MISR 21116 & $>256$ & 128 & 64 & 128 & 64 & 32 & 32 & na \\
\hline V. vulnificus MISR 20716 & - & - & 128 & 256 & 32 & 64 & 32 & na \\
\hline V. alginolyticus MISR 30816 & - & - & 256 & 128 & $>256$ & 32 & 64 & na \\
\hline \multicolumn{9}{|c|}{ Gram positive bacteria } \\
\hline E. faecalis ATCC 29212 & - & - & $>256$ & $>256$ & 8 & 128 & 32 & na \\
\hline S. aureus ATCC 25923 & $>256$ & 16 & 32 & 64 & 16 & 16 & 4 & na \\
\hline B. subtilis ATCC 6633 & - & 128 & 64 & 64 & 8 & 16 & 32 & na \\
\hline B. cereus MISR 12818 & - & 128 & 64 & 64 & 32 & 16 & 64 & na \\
\hline Rhodococcus sp. MISR 16518 & - & 32 & 64 & 128 & 16 & 8 & 32 & na \\
\hline \multicolumn{9}{|c|}{ Fungi } \\
\hline C. albicans ATCC 10231 & - & 128 & 64 & 64 & na & na & na & 32 \\
\hline A. niger MISR 11215 & - & 64 & 64 & 64 & na & na & na & 8 \\
\hline F. oxisporum MISR 20415 & $>256$ & 64 & 64 & 64 & na & na & na & 32 \\
\hline R. solani MISR 11115 & $>256$ & 64 & 64 & 64 & na & na & na & 32 \\
\hline
\end{tabular}

Amp—ampicillin; Kan—kanamycin; Tet—tetracycline; Mic—miconazole; “-“: no activity; na: not applicable.

\section{Discussion}

\subsection{Cultivable Bacteria from Vietnamese Sponges}

It is well known that bacteria associated with marine sponges are phylogenetically diverse and an important source of bioactive compounds, including antimicrobial compounds [22,25-27]. The present study aimed to isolate bacteria associated with Vietnamese sponges, which have only been studied very little, and screen for antimicrobial activity of the isolated strains. The 16S rRNA gene sequence analysis showed that cultivable bacteria from the Vietnamese sponges belonged to four phyla, which is much lower compared to the 15 phyla that were detected by direct Illumina MiSeq amplicon sequencing analysis of the same sponge samples [28]. This discrepancy has also been observed in previous investigations of sponge-associated bacteria using both cultivation-dependent and -independent approaches [34-38]. The failure of obtaining the diverse bacteria associated with sponges by cultivation can be partially explained by the failure to mimic the natural growth conditions of sponge-associated bacteria (e.g., host-symbiont interactions, substrates required for growth) in the laboratory. Recent developments in reconstructing composite genomes of currently uncultivable bacteria out of metagenomes have provided clues on growth substrates of some sponge-associated bacteria, e.g., predicted consumption of carnitine, spermidine, and sulfated polysaccharides [39,40], compounds that are hardly ever included in bacterial cultivation media. In addition, extensive cultivation efforts by using alternative techniques (e.g., cultivation media and growth condition diversification, liquid culture, floating filter, diffusion chamber cultivation) have improved the cultivability of sponge-associated bacteria and should be used in more bacterial cultivation experiments with sponges [35,38,41,42].

At the genus level, cultivable bacteria from Vietnamese sponges were predominated by genera such as Bacillus, Pseudovibrio, and Ruegeria, which are commonly isolated from marine sponges [35,36,41,43-47]. A cultivable Pseudovibrio sp. has also been found in sponge larvae and may thus represent a bacterium that is vertically transmitted in sponges [45]. Despite their predominance in our cultivation experiment, these genera were not detected, or were detected at very low relative abundance, in the same sponge specimens by direct Illumina MiSeq amplicon sequencing analysis [28]. 
It is possible that these bacteria may be selected for cultivation experiments as they may grow quickly in rich-nutrient media and outcompete other slow-growing species, although they are not abundant in the original inoculum [48].

In addition, several common genera, such as Pseudovibrio, Bacillus, Vibrio, and Ruegeria grew well on different cultivation media, suggesting that these genera can adapt well to different cultivation media and conditions. Recent genome studies have reported that genomes of these genera contain the genetic machinery encoding for a versatile metabolism and harbor diverse genomic features linked to symbiosis and lifestyles allowing for host switching [49-61].

\subsection{Antimicrobial Activity of Sponge-Associated Bacteria}

Marine sponges are sessile organisms, and their defense mechanism against predators (e.g., bacteria, eukaryotic organisms, viruses) is mainly based on the production of a diverse range of secondary metabolite products, allowing efficient chemical protection [62-64]. Increasing evidence has shown that many bioactive compounds, including antimicrobial compounds [22,25-27], from sponges are produced by their microbial symbionts $[23,24,65-69]$. The antimicrobial screening assay of cultured bacteria in this study showed that approximately $20 \%$ of the isolated strains exhibited antimicrobial activity. It was observed that strains showed more activity against Gram-positive bacteria than Gram-negative bacteria. The difference in membrane structure between Gram-positive and Gram-negative bacteria could partially explain their different sensitivity to antimicrobial agents. The outer membrane of Gram-negative bacteria is covered by a layer of lipopolysaccharide, which protects them from antibiotics attacking the peptidoglycan layer [70]. Among the isolated strains with antimicrobial activity, Bacillus, Streptomyces, and Pseudovibrio were the most frequently obtained. These genera have been reported as major producers of bioactive compounds with antimicrobial activity in sponges [27]. Genome analyses of sponge-derived isolated bacteria from these genera have reported that they contain a large number of secondary metabolite biosynthesis gene clusters [50,53-55,71-73]. One Bacillus isolated strain (M1_CRV_171) inhibited the growth of Gram-positive and Gram-negative bacteria and fungi. The genus Bacillus produces versatile antimicrobials with diverse structures (e.g., polyketides, ribosomal peptides, non-ribosomal peptides, lipopeptides, macrolactones, polypeptides, isocoumarins) [74-76]. A large-scale analysis of 1566 genomes of Bacillus strains resulted in identifying nearly 20,000 biosynthetic gene clusters (BGCs) [77]. Of these, a large number of BGCs encode the enzymes required for the production of unknown compounds, indicating Bacillus as a prolific source of secondary metabolites. It is estimated that at least $4-8 \%$ of the genome of Bacillus is devoted to synthesizing antimicrobial compounds [78-80].

Among the antimicrobial isolated strains, the strain Bacillus sp. M1_CRV_171 is one of the cultured strains that was found in the cultivation-independent bacterial community analysis (OTU909). Therefore, this isolated strain was subjected to investigation of its secondary metabolites. From culture broth of Bacillus sp. M1_CRV_171, one cyclic dipeptide, cyclo(L-pro-L-tyr) (1), was isolated and purified. This cyclic dipeptide has been reported to be produced by different bacteria (i.e., Bacillus, Pseudomonas, Ruegeria, Psychrobacter) associated with different sponges [81-86], indicating that it may play a role in the sponge holobiont. The antimicrobial assays in our study showed that cyclo(L-pro-L-tyr) exhibited antimicrobial activity against $S$. aureus, V. parahaemolyticus, F. oxisporum, and R. solani and showed no activity against the other tested microorganisms. This confirms previous bioactivity investigations of cyclo(L-pro-L-tyr), which reported that this cyclic dipeptide exhibits antimicrobial activity against several bacteria and plant pathogenic fungi, such as S. epidermis, Klebsiella pneumoniae, Proteus mirabilis, and V. cholerae [87], Micrococcus luteus, S. aureus, S. enterica, E. coli, and Fusarium sp. [88], Xanthomonas axonopodis pv. citri, and Ralstonia solanacearum [29], F. oxysporum and Penicillium sp. [89], A. niger [90], Phytophthora infestans, and Plasmopara viticola [91,92]. However, cyclic dipeptides, including cyclo(L-proL-tyr), have gained more attention because of their role as quorum sensing (QS) signal 
molecules [93-100]. It has been reported that sponge-associated bacteria, as well as cyclic dipeptides isolated from sponge-associated bacteria, are involved in QS by activating acyl homoserine lactones (AHLs) bioreporters [85]. AHLs are QS signal molecules mainly produced by Gram-negative bacteria and may directly bind to transcription factors (e.g., LuxR) to regulate gene expression [101,102], indicating that these bacteria and cyclic dipeptides may interact with AHL producers and play a certain role in QS. Interestingly, previous studies have demonstrated the production of AHLs by both sponges and their associated bacteria [103-106], and these compounds may thus be involved in communication in the sponge holobiont.

Furthermore, three macrolides 2-4 were isolated from culture broth of Bacillus sp. M1_CRV_171. Macrolide compounds are widely used as antibiotics in clinics (e.g., erythromycin) and display different biological activities, including modulating inflammation [107]. Macrolactins are a large group of macrolide antibiotics with a 22- to 24-member lactone ring mainly discovered in marine microorganisms, especially in the genus Bacillus [74,108]. Although numerous macrolide compounds have been isolated and identified from sponges and their symbionts [108], this is the first study to report the isolation of macrolactins from sponge-associated bacteria. Macrolactin A (2) has been frequently isolated from different bacteria [30-32,109-112], whereas macrolactin $H(3)$ and 15, 17epoxy-16-hydroxy macrolactin A (4) have been rarely isolated [32,33]. Previous bioassays revealed that macrolactin A exhibited antimicrobial activity against Gram-negative bacteria (i.e., E. coli), Gram-positive bacteria (i.e., S. aureus, methicillin-sensitive S. aureus (MSSA), methicillin-resistant $S$. aureus (MRSA), B. subtilis, E. faecalis, and vancomycin-resistant enterococci), as well as fungi (i.e., Botrytis cinerea, A. niger, B. cinerea, Colletotrichum acutatum, R. solani, S. cerevisiae, C. albicans, Pestalotiopsis theae, and C. gloeosporioides) [30-32,109-112]. The antimicrobial assays in our studies showed similar results, in which macrolactin A exhibited antimicrobial activity against a broad spectrum of reference microorganisms. Furthermore, antibacterial activity of macrolactin A against Vibrio spp. was reported for the first time in this study. The biological properties of macrolactin $\mathrm{H}$ (3) and 15, 17-Epoxy-16hydroxy macrolactin A (4) are less well known. The isolation and antimicrobial activity of these two compounds have been reported once by [33] and [32], respectively. Macrolactin $\mathrm{H}$ was reported to exhibit antimicrobial activity against $S$. aureus (MIC $=10 \mu \mathrm{g} / \mathrm{mL}$ ) and B. subtilis (MIC $=60 \mu \mathrm{g} / \mathrm{mL}$ ) [32], whereas 15, 17-epoxy-16-hydroxy macrolactin A was reported to exhibit antimicrobial activity against $B$. subtilis, E. coli, and $S$. cerevisiae with the same MICs of $0.16 \mu \mathrm{M}$ [33]. Although macrolactins show antimicrobial activity against a broad spectrum of microorganisms, including Gram-negative and Gram-positive bacteria and fungi, the mode of action of macrolactins is not understood. However, several recent studies indicate that some macrolactin compounds, such as 7-O-Malonyl Macrolactin A, induce disruption of cell division [31] and macrolactin $\mathrm{N}$ inhibits bacterial peptide deformylase [113], whereas bamemacrolactin C affects fungal mycelial morphology, the cell wall, and protein expression by interrupting the oxidative phosphorylation [114]. In addition, Zotchev et al. [115] speculate that the antibacterial activity of macrolactins could be due to the inhibition of the $\mathrm{H}^{+}$-transporting two-sector ATPase, which is essential for viability of bacterial cells.

\section{Materials and Methods}

\subsection{Collection and Identification of Sponges}

Sponge specimens were collected by Scuba diving from May to September 2015 from the central coastal region of Vietnam at 5-10 m depth and identified using molecular markers (18S rRNA and cytochrome oxidase I (COI) genes) in a previous study: Axinyssa sp., Xestospongia testudinaria, Clathria reinwardti, Spirastrella sp., Dactylospongia sp., Haliclona amboinensis, Cinachyrella schulzei, Niphatidae sp., Haliclona fascigera, Amphimedon sp. (1), Amphimedon sp. (2), Haplosclerida sp., Rhabdastrella globostellata, Spheciospongia sp., Halichondria sp., Tedania sp., Terpios aploos, and Axos cliftoni [28]. 


\subsection{Isolation of Bacteria from Sponges}

The sponge specimens were rinsed three times with sterile seawater to remove bacteria attached to the surface of sponges. The specimens were then further cleaned with a sterile scalpel in order to remove sediment and other organisms attached to the sponge. A piece of sponge specimen $\left(\sim 1 \mathrm{~cm}^{3}\right)$ was crushed with a sterile mortar and pestle and then homogenized in 10 volumes of sterile seawater. The cell suspension was serially diluted till $10^{-6}$ and subsequently plated onto seven different media: MA $(0.5 \%$ peptone, $0.1 \%$ yeast extract, $1.5 \%$ agar) (modified from [116]); M1 (1.0\% starch, $0.4 \%$ yeast extract, $0.2 \%$ peptone, $1.5 \%$ agar) (modified from [117]); R2A ( $0.05 \%$ yeast extract, $0.05 \%$ glucose, $0.05 \%$ peptone, $0.05 \%$ casein hydrolysate, $0.05 \%$ starch, $0.03 \%$ sodium pyruvate, $0.03 \% \mathrm{~K}_{2} \mathrm{HPO}_{4}$, $0.005 \% \mathrm{MgSO}_{4}, 1.5 \%$ agar) (modified from [118]); SCA (0.5\% starch, $0.002 \%$ casein, $0.1 \%$ $\mathrm{KNO}_{3}, 0.1 \% \mathrm{NaCl}, 0.1 \% \mathrm{~K}_{2} \mathrm{HPO}_{4}, 0.5 \mathrm{~mL} / \mathrm{L} \mathrm{MgSO}_{4} 100 \mathrm{mM} ; 0.5 \mathrm{~mL} / \mathrm{L} \mathrm{FeSO}_{4} 100 \mathrm{mM}$, $0.5 \mathrm{~mL} / \mathrm{L} \mathrm{CaCO}_{3} 100 \mathrm{mM}, 1.5 \%$ agar) (modified from [119]); AIA (0.01\% peptone, $0.001 \%$ L-asparagine, $0.4 \%$ sodium propionate, $0.005 \% \mathrm{~K}_{2} \mathrm{HPO}_{4}, 0.001 \% \mathrm{MgSO}_{4}, 0.001 \mathrm{~g} / \mathrm{L} \mathrm{FeSO}_{4}$, $1 \mathrm{~mL} / \mathrm{L}$ glycerol, $1.5 \%$ agar) [35]; OLIGO ( $0.05 \%$ yeast extract, $0.05 \%$ tryptone, $0.01 \%$ sodium glycerolphosphate, $1.5 \%$ agar) [120]; SWA (1.5\% agar). Nalidixic acid and cycloheximide were supplemented into culture media at concentrations of $100 \mu \mathrm{g} / \mathrm{L}$ and $25 \mu \mathrm{g} / \mathrm{L}$, respectively, to reduce growth of fast-growing Gram-negative bacteria and fungi. All culture media were prepared with sterile natural seawater at $\mathrm{pH} 7.8$ and all plates were produced in triplicate and incubated for $3-5$ days at $30^{\circ} \mathrm{C}$. The pure cultures were obtained by streaking on agar plates and were stored with $20 \%$ glycerol $(v / v)$ at $-80{ }^{\circ} \mathrm{C}$ at the Mientrung Institute for Scientific Research, Hue city, Thua Thien Hue province, Vietnam.

\subsection{Screening for Antimicrobial Activity of the Isolates}

The isolates $(n=460)$ were incubated in M1 broth under aerobic conditions on a rotary shaker $(150 \mathrm{rpm})$ at $30^{\circ} \mathrm{C}$ until they reached the stationary phase, then the cultures were centrifuged at $14,000 \times g$ for $10 \mathrm{~min}$. The cell-free supernatants were used for screening their antimicrobial activity.

Antimicrobial activity of the isolates was tested against seven indicator strains, including Gram positive bacteria: Bacillus subtilis ATCC 6633, Staphylococcus aureus ATCC 25923, Enterococcus faecalis ATCC 29212, Gram negative bacteria: Escherichia coli ATCC 25922, Pseudomonas aeruginosa ATCC 27853, Salmonella enterica ATCC 13076, and the yeast Candida albicans ATCC 10231 using the agar well diffusion method. The indicator bacteria were grown in nutrient broth (NB), whereas the yeast was grown in potato dextrose agar (PDA). All indicator strains were grown aerobically on a rotary shaker $(150 \mathrm{rpm})$ overnight and then the density of the strains in cultures was adjusted to an $\mathrm{OD}_{600}$ of 0.5 . Subsequently, $100 \mu \mathrm{L}$ of these growing cultures was spread on Mueller-Hinton (MH) agar (for bacteria) and RMPI agar supplemented with $2 \%$ glucose (for yeast). The agar wells were prepared by using a sterilized cork borer ( $6 \mathrm{~mm}$ in diameter). Antimicrobial activity of the isolates was examined by adding $100 \mu \mathrm{L}$ of the cell-free supernatant of each isolate to the wells. For the negative controls, $100 \mu \mathrm{L}$ of the respective sterile, uninoculated liquid media was added to the $6 \mathrm{~mm}$ wells. For positive controls, Ampicillin (10 $\mu \mathrm{g})$, Kanamycin $(30 \mu \mathrm{g})$, and Tetracycline $(30 \mu \mathrm{g})$ were added to the $6 \mathrm{~mm}$ wells. The assay was conducted in triplicate for each of the indicator strains.

The agar plates were incubated at $35^{\circ} \mathrm{C}$ for $24 \mathrm{~h}$ (for the indicator bacteria) and $28{ }^{\circ} \mathrm{C}$ for $48 \mathrm{~h}$ (for the yeast). After incubation, antimicrobial activity of isolates was determined based on the formation of inhibition zones around wells.

\subsection{Identification of the Isolates by $16 \mathrm{~S} r R N A$ Gene Analysis}

The glycerol stocks of picked isolates were regrown in the liquid media that were used for their initial isolation. The regrown isolates were identified by colony PCR. For cell lysis, the liquid cultures $(2 \mathrm{~mL})$ were centrifuged at $14,000 \times g$ for $10 \mathrm{~min}$ and the obtained pellets were suspended in $50 \mu \mathrm{L}$ nuclease-free water. Subsequently, the cell suspension was stored at $-20^{\circ} \mathrm{C}$ for $2 \mathrm{~h}$, followed by incubation at $98^{\circ} \mathrm{C}$ for $10 \mathrm{~min}$. The $16 \mathrm{~S}$ rRNA gene 
of isolates was directly amplified with universal primers: $27 \mathrm{f}$ and $1492 \mathrm{r}$ [121] through the following PCR program: an initial denaturation at $94^{\circ} \mathrm{C}$ for $5 \mathrm{~min}$, followed by 30 cycles of denaturation at $94{ }^{\circ} \mathrm{C}$ for $1 \mathrm{~min}$, annealing at $56{ }^{\circ} \mathrm{C}$ for $50 \mathrm{~s}$, amplification at $72{ }^{\circ} \mathrm{C}$ for $1.5 \mathrm{~min}$, and a final extension at $72{ }^{\circ} \mathrm{C}$ for $7 \mathrm{~min}$. The $16 \mathrm{~S}$ rRNA gene sequencing was carried with a ABI PRISM $3100^{\circledR}$ Genetic Analyzer (Applied Bioscience and Hitachi, Foster city, CA, USA) with primers $27 \mathrm{f}$ and $907 \mathrm{r} / 1492 \mathrm{r}$ [122] to facilitate alignment with Illumina MiSeq sequencing reads that were used to characterize the prokaryotic communities of the sponges previously [28]. The sequences were quality checked, and low-quality regions were removed from the sequence ends using BioEdit software v.7.2.6.1. The quality-checked sequences of the isolates were compared to available sequences in the NCBI GenBank using BLAST v.2.7.1+ [123], with the algorithm megablast and the database nt (5 September 2018).

Alpha diversity indices (i.e., observed richness $S$, Shannon diversity index $H$, inverse Simpson In, Pielou's evenness $J$ ) were calculated in R v.3.0.3 with the vegan package [124,125]. The relative abundance of the cultivable bacteria at the genus level from different sponge species and media was visualized with JColorGrid [126].

To compare the sequences of the isolates to the cultivation-independent fraction, 16S rRNA gene sequences of the isolates in this study were blasted against Illumina MiSeq sequences of prokaryotic OTUs from the same sponge specimens described in the previous study [28] using a BLAST search [123]. A match was defined as sequences shared between the cultivation-dependent fraction and cultivation-independent fraction if their identity was $100 \%$. The relative abundance of the shared OTUs from the cultivation fraction and cultivation-independent fraction was visualized with JColorGrid [126].

\subsection{Cultivation, Extraction, and Isolation of Secondary Metabolites}

The strain Bacillus sp. M1_CRV_171 was cultured in a $250 \mathrm{~mL}$ flask containing $125 \mathrm{~mL}$ M1 broth at $30{ }^{\circ} \mathrm{C}$ for $48 \mathrm{~h}$ in a shaking incubator. The culture was transferred to a $5 \mathrm{~L}$ bioreactor (BioFlo 120, Eppendorf, Hamburg, Germany) containing 2.5 L M1 broth with an inoculum of $5 \%(v / v)$. The reactor was operated at $30^{\circ} \mathrm{C}$ with agitation of $150 \mathrm{rpm}$ for $48 \mathrm{~h}$. Subsequently, the culture was used to inoculate a $100 \mathrm{~L}$ bioreactor (BioFlo 610, Eppendorf, Hamburg, Germany) containing 50 L M1 medium with an inoculum $5 \%(v / v)$. The reactor was operated at $30^{\circ} \mathrm{C}$ with agitation of $150 \mathrm{rpm}$ for 7 days. The culture broth $(50 \mathrm{~L})$ was extracted with ethyl acetate ( $25 \mathrm{~L} \times 3$ times) at room temperature. The ethyl acetate extract was concentrated under a reduced pressure to yield $11.0 \mathrm{~g}$ of crude residue. The residue was subjected to a silica gel chromatography column (CC) (Kiesel gel 60, 70-230 mesh, and 230-400 mesh, Merck, Germany) and eluted with a dichloromethane/methanol gradient $(100 / 1$ to $1 / 100, v / v)$ to give seven fractions VKB1-VKB7. The fraction VKB2 was chromatographed on an RP-18 column (30-50 $\mu \mathrm{m}$, Fuji Silysia Chemical Ltd., Kasugai Aichi, Japan) and eluted with methanol/water $(1 / 1, v / v)$ to obtain compound $2(17.8 \mathrm{mg})$ and a subfraction VKB2.1. Compound $\mathbf{1}(6.3 \mathrm{mg})$ was obtained from fraction VKB2.1 by silica gel CC, eluted with dichloromethane/methanol $(30 / 1, v / v)$. The fraction VKB3 was subjected to a silica gel CC and eluted with dichloromethane/methanol $(30 / 1, v / v)$ to give two smaller fractions VKB3.1-VKB3.2. The fraction VKB3.1 was further separated on an $\mathrm{RP}-18$ column and eluted with methanol/water $(1.5 / 1, v / v)$ to give compound $3(3.7 \mathrm{mg})$. Compound $4(3.4 \mathrm{mg})$ was purified from the fraction VKB3.2 on an RP-18 column eluted with methanol/water $(1.5 / 1, v / v)$.

The electrospray ionization mass spectra (ESI-MS) of the compounds were recorded on a MicroQ-TOF III mass spectrometer (Bruker Daltonics, Bremen, Germany), and the NMR spectra ( ${ }^{1} \mathrm{H}$ NMR, ${ }^{13} \mathrm{C}$ NMR, HMBC, HSQC) of the compounds were recorded on a Bruker Avance III HD 500 FT NMR spectrometer (Bruker BioSpin, Rheinstetten, Germany) with TMS as an internal standard. The optical rotations were recorded on a JASCO P-2000 digital polarimeter (JASCO, Tokyo, Japan). The structures of the isolated compounds were elucidated by the examination of their ESI-MS, NMR spectra and compared with reported data. 
Compound 1 (Cyclo(L-Pro-L-Tyr)): white solid; ESI-MS $m / z 261.1[\mathrm{M}+\mathrm{H}]^{+} ;[\alpha]_{\mathrm{D}}{ }^{24}=-17.5$ (c $0.05, \mathrm{MeOH}) ;{ }^{1} \mathrm{H}$ NMR $\left(500 \mathrm{MHz}, \mathrm{CD}_{3} \mathrm{OD}\right) \delta_{\mathrm{H}}(\mathrm{ppm}): \delta_{\mathrm{H}} 1.82(2 \mathrm{H}, \mathrm{m}, \mathrm{H}-4), 2.11(2 \mathrm{H}$, m, H-5), 3.07 (2H, m, H-10), $3.37\left(1 \mathrm{H}, \mathrm{m}, \mathrm{H}_{\mathrm{a}}-3\right), 3.57\left(1 \mathrm{H}, \mathrm{m}, \mathrm{H}_{\mathrm{b}}-3\right), 4.07(1 \mathrm{H}, \mathrm{m}, \mathrm{H}-6), 4.37$ $(1 \mathrm{H}, \mathrm{m}, \mathrm{H}-9), 6.72\left(2 \mathrm{H}, \mathrm{d}, J=8.5 \mathrm{~Hz}, \mathrm{H}-3^{\prime}, 5^{\prime}\right), 7.05\left(2 \mathrm{H}, \mathrm{d}, J=8.5 \mathrm{~Hz}, \mathrm{H}-2^{\prime}, 6^{\prime}\right)$; ${ }^{13} \mathrm{C} \mathrm{NMR}$ $\left(125 \mathrm{MHz}, \mathrm{CD}_{3} \mathrm{OD}\right) \delta_{\mathrm{C}}(\mathrm{ppm}): \delta_{\mathrm{C}} 22.7$ (C-4), 29.3 (C-5), 37.6 (C-10), 45.9 (C-3), 57.9 (C-9), 60.0 (C-6), $116.2\left(\mathrm{C}-3^{\prime}, 5^{\prime}\right), 127.6\left(\mathrm{C}-1^{\prime}\right), 132.1$ (C-2', 6'), 157.6 (C-4'), 166.9 (C-1), 170.8 (C-7).

Compound 2 (Macrolactin A): amorphous solid; ESI-MS $m / z 403.2[\mathrm{M}+\mathrm{H}]^{+} ;[\alpha]_{\mathrm{D}}{ }^{24}=-8.3$ (c $0.10, \mathrm{MeOH}) ;{ }^{1} \mathrm{H}$ NMR $\left(500 \mathrm{MHz}, \mathrm{CD}_{3} \mathrm{OD}\right) \delta_{\mathrm{H}}(\mathrm{ppm}): \delta_{\mathrm{H}} 1.27(3 \mathrm{H}, \mathrm{d}, J=6.5 \mathrm{~Hz}, \mathrm{H}-24)$, $1.52(2 \mathrm{H}, \mathrm{m}, \mathrm{H}-21), 1.59$ (1H, m, Ha -22$), 1.63$ (2H, m, H-14), 1.65 (1H, m, H $\left.\mathrm{H}_{\mathrm{a}}-20\right), 2.20\left(1 \mathrm{H}, \mathrm{m}, \mathrm{H}_{\mathrm{b}}-20\right), 2.34\left(1 \mathrm{H}, \mathrm{m}, \mathrm{H}_{\mathrm{a}}-12\right), 2.44(2 \mathrm{H}, \mathrm{m}, \mathrm{H}-6), 2.50\left(1 \mathrm{H}, \mathrm{m}, \mathrm{H}_{\mathrm{b}}-12\right), 3.87$ (1H, m, H-13), 4.28 (1H, m, H-7), 4.32 (1H, m, H-15), 5.02 (1H, m, H-23), 5.55 (1H, m, H-11), $5.56(1 \mathrm{H}, \mathrm{m}, \mathrm{H}-2), 5.57(1 \mathrm{H}, \mathrm{m}, \mathrm{H}-16), 5.66(1 \mathrm{H}, \mathrm{m}, \mathrm{H}-19), 5.77(1 \mathrm{H}, \mathrm{dd}, J=6.0,15.0 \mathrm{~Hz}, \mathrm{H}-8)$, 6.05 (1H, m, H-18), 6.10 (1H, m, H-17), 6.13 (1H, m, H-10), 6.19 (2H, m, H-5), 6.58 (1H, dd, $J=11.0,15.0 \mathrm{~Hz}, \mathrm{H}-9), 6.65(1 \mathrm{H}, \mathrm{t}, J=11.5 \mathrm{~Hz}, \mathrm{H}-3), 7.23(1 \mathrm{H}, \mathrm{m}, \mathrm{H}-4) ;{ }^{13} \mathrm{C} \mathrm{NMR}(125 \mathrm{MHz}$, $\left.\mathrm{CD}_{3} \mathrm{OD}\right) \delta_{\mathrm{C}}(\mathrm{ppm}): \delta_{\mathrm{C}} 20.1(\mathrm{C}-24), 25.6$ (C-21), 32.9 (C-20), 36.1 (C-22), $36.4(\mathrm{C}-12), 42.8$ (C-6), 43.9 (C-14), 69.2 (C-13), 69.8 (C-15), 72.2 (C-23), 72.3 (C-7), 117.9 (C-2), 125.9 (C-9), 128.4 (C-11), 130.2 (C-4), 131.2 (C-17), 131.3 (C-10), 131.7 (C-18), 135.1 (C-19), 135.2 (C-16), 137.5 (C-8), 142.1 (C-5), 144.9 (C-3), 168.0 (C-1).

Compound 3 (Macrolactin H): amorphous solid; ESI-MS $m / z 377.3[\mathrm{M}+\mathrm{H}]^{+} ;[\alpha]_{\mathrm{D}}{ }^{24}=-24.6$ (c $0.05, \mathrm{MeOH}) ;{ }^{1} \mathrm{H}$ NMR $\left(500 \mathrm{MHz}, \mathrm{CD}_{3} \mathrm{OD}\right) \delta_{\mathrm{H}}(\mathrm{ppm}): \delta_{\mathrm{H}} 1.27(3 \mathrm{H}, \mathrm{d}, J=6.5 \mathrm{~Hz}, \mathrm{H}-22)$, 1.40 (2H, m, H-19), 1.58 (1H, m, Ha -12$), 1.59$ (2H, m, H-14), 1.65 (1H, m, Ha -20$), 2.08$ (2H, m, $\mathrm{H}-18), 2.33$ (1H, m, H (1H, m, H-13), 4.98 (1H, m, H-7), 5.46 (1H, m, H-11), 5.55 (2H, m, H-2, 16), 5.59 (1H, m, H-4), $5.63(1 \mathrm{H}, \mathrm{m}, \mathrm{H}-10), 5.65$ (2H, m, H-3, 17), 5.76 (1H, m, H-8), $6.17(1 \mathrm{H}, \mathrm{m}, \mathrm{H}-5), 6.75(1 \mathrm{H}, \mathrm{m}$, $\mathrm{H}-9) ;{ }^{13} \mathrm{C}$ NMR $\left(125 \mathrm{MHz}, \mathrm{CD}_{3} \mathrm{OD}\right) \delta_{\mathrm{C}}(\mathrm{ppm}): \delta_{\mathrm{C}} 166.3$ (C-1), $118.0(\mathrm{C}-2), 144.8(\mathrm{C}-3), 130.4$ (C-4), 141.7 (C-5), 42.5 (C-6), 72.0 (C-7), 137.2 (C-8), 126.1 (C-9), 131.0 (C-10), 134.7 (C-11), 36.5 (C-12), 69.7 (C-13), 44.6 (C-14), 70.2 (C-15), 128.3 (C-16), 131.7 (C-17), 32.9 (C-18), 25.9 (C-19), 36.6 (C-20), 70.8 (C-21), 20.1 (C-22).

Compound 4 (15,17-epoxy-16-hydroxy macrolactin A): amorphous powder; ESI-MS $m / z 419.3[\mathrm{M}+\mathrm{H}]^{+} ;[\alpha]_{\mathrm{D}}{ }^{24}=-37.2(\mathrm{c} 0.01, \mathrm{MeOH}) ;{ }^{1} \mathrm{H}$ NMR $\left(500 \mathrm{MHz}, \mathrm{CD}_{3} \mathrm{OD}\right) \delta_{\mathrm{H}}(\mathrm{ppm})$ : $\delta_{\mathrm{H}} 1.28(3 \mathrm{H}, \mathrm{d}, J=6.0 \mathrm{~Hz}, \mathrm{H}-24), 1.40\left(1 \mathrm{H}, \mathrm{m}, \mathrm{H}_{\mathrm{a}}-14\right), 1.52(2 \mathrm{H}, \mathrm{m}, \mathrm{H}-21), 1.67$ (2H, m, H-22), $1.99\left(1 \mathrm{H}, \mathrm{m}, \mathrm{H}_{\mathrm{b}}-14\right), 2.05\left(1 \mathrm{H}, \mathrm{m}, \mathrm{H}_{\mathrm{a}}-20\right), 2.11\left(1 \mathrm{H}, \mathrm{m}, \mathrm{H}_{\mathrm{b}}-20\right), 2.13\left(1 \mathrm{H}, \mathrm{m}, \mathrm{H}_{\mathrm{a}}-12\right), 2.42(1 \mathrm{H}$, $\left.\mathrm{m}, \mathrm{H}_{\mathrm{a}}-6\right), 2.51\left(1 \mathrm{H}, \mathrm{m}, \mathrm{H}_{\mathrm{b}}-6\right), 2.57\left(1 \mathrm{H}, \mathrm{m}, \mathrm{H}_{\mathrm{b}}-12\right), 2.94(1 \mathrm{H}, \mathrm{t}, J=9.0 \mathrm{~Hz}, \mathrm{H}-16), 3.46(2 \mathrm{H}$, m, H-13, 17), 3.54 (1H, m, H-15), 4.27 (1H, m, H-7), 4.98 (1H, m, H-23), 5.46 (1H, m, H-11), $5.54(1 \mathrm{H}, \mathrm{d}, J=11.5 \mathrm{~Hz}, \mathrm{H}-2), 5.64(1 \mathrm{H}, \mathrm{m}, \mathrm{H}-8), 5.67(1 \mathrm{H}, \mathrm{m}, \mathrm{H}-18), 5.70(1 \mathrm{H}, \mathrm{m}, \mathrm{H}-19)$, $6.07(1 \mathrm{H}, \mathrm{t}, J=11.0 \mathrm{~Hz}, \mathrm{H}-10), 6.27(1 \mathrm{H}, \mathrm{m}, \mathrm{H}-5), 6.56(1 \mathrm{H}, \mathrm{dd}, J=11.0,15.0 \mathrm{~Hz}, \mathrm{H}-9), 6.67$ $(1 \mathrm{H}, \mathrm{t}, J=11.5 \mathrm{~Hz}, \mathrm{H}-3), 7.25(1 \mathrm{H}, \mathrm{m}, \mathrm{H}-4) ;{ }^{13} \mathrm{C}$ NMR $\left(125 \mathrm{MHz}, \mathrm{CD}_{3} \mathrm{OD}\right) \delta_{\mathrm{C}}(\mathrm{ppm}): \delta_{\mathrm{C}} 19.8$ (C-24), 26.6 (C-21), 34.4 (C-20), 35.1 (C-12), 36.8 (C-22), 40.8 (C-14), 42.7 (C-6), 72.9 (C-23), 73.1 (C-7), 73.9 (C-15), 76.0 (C-13), 77.7 (C-16), 80.2 (C-17), 118.2 (C-2), 127.7 (C-9), 129.1 (C-18), 129.5 (C-11), 130.6 (C-4), 131.4 (C-10), 132.2 (C-19), 136.2 (C-8), 141.4 (C-5), 144.6 (C-3), $168.2(\mathrm{C}-1)$.

\subsection{Antimicrobial Activity of the Secondary Metabolites}

Antimicrobial activities of the isolated secondary metabolites 1-4 were tested against a broad spectrum of reference microorganisms. Besides the seven reference microorganisms used for antimicrobial screening assays of isolated strains (see above), antimicrobial activity was evaluated against several microbial plant and aquaculture pathogens isolated in Vietnam: P. putida MISR 71218, Rhodococcus sp. MISR 16518, B. cereus MISR 12818, Vibrio parahaemolyticus MISR 21116, V. vulnificus MISR 20716, V. alginolyticus MISR 30816, Aspergillus niger MISR-11215, Fusarium oxisporum MISR 20415, and Rhizoctonia solani MISR 11115.

MICs of the secondary metabolites against reference microorganisms were determined using the broth microdilution method. Determination of MICs of the isolated compounds against the indicator bacteria was performed according to recommendations of the Euro- 
pean Committee on Antimicrobial Susceptibility Testing (EUCAST) discussion document E.Dis 5.1 [127]. Briefly, the isolated compounds were dissolved in dimethyl sulfoxide (DMSO) and serially two-fold diluted in $\mathrm{MH}$ broth to a concentration range that was twice the desired final concentration $(0.5-512 \mu \mathrm{g} / \mathrm{mL})$ and obtained by adding an equal volume of indicator bacteria cell suspension (see below). $100 \mu \mathrm{L}$ of the compound solutions were added to wells of 96 -well plates. The indicator Bacteria were then incubated overnight in $\mathrm{NB}$ on a rotary shaker $(150 \mathrm{rpm})$ at $37^{\circ} \mathrm{C}$, then the density of strains was adjusted to a McFarland standard of 0.5 , which contains approximately $1.5 \times 10^{8} \mathrm{CFU} / \mathrm{mL}$ (range 1-2 $\times 10^{8} \mathrm{CFU} / \mathrm{mL}$ ). The bacterial solution was subsequently diluted 150 -fold in $\mathrm{MH}$ broth to reach a starting inoculum of $1 \times 10^{6} \mathrm{CFU} / \mathrm{mL}$. Finally, $100 \mu \mathrm{L}$ of this inoculum was added to wells containing $100 \mu \mathrm{L}$ of the compound solution (see above) to obtain a final inoculum of $5 \times 10^{5} \mathrm{CFU} / \mathrm{mL}$. The plates included growth control wells (inoculated in compound-free medium) and sterile (uninoculated) wells. The plate was incubated at $37^{\circ} \mathrm{C}$ for $24 \mathrm{~h}$, then the absorbance at $630 \mathrm{~nm}$ was measured using a microplate reader. The MIC was defined as the lowest concentration of a compound, at which there was no visible growth of indicator bacteria.

Determination of MICs of the isolated compounds against the yeast (C. albicans) was performed as recommended in the EUCAST definitive document E.DEF 7.3 [128]. The isolated compound solutions were diluted to the same concentrations $(0.5-512 \mu \mathrm{g} / \mathrm{mL})$ as the antibacterial assay in double strength RPMI 1640 broth (with L-glutamine and a pH indicator but without bicarbonate), supplemented with glucose to a final concentration of $2 \%$ (RPMI $2 \% \mathrm{G}$ ), similar to the above-described concentrations. The yeast strain was grown on PDA at $35^{\circ} \mathrm{C}$ for $48 \mathrm{~h}$, then colonies were suspended in $10 \mathrm{~mL}$ distilled water. The suspension was homogenized by vortexing for $15 \mathrm{~s}$. Subsequently, the cell density was adjusted to the $0.5 \mathrm{McF}$ arland standard, which contains approximately $1-5 \times 10^{6} \mathrm{CFU} / \mathrm{mL}$ by measuring the absorbance at a wavelength of $530 \mathrm{~nm}$. The yeast solution was diluted 10 -fold in sterile distilled water to obtain a starting inoculum of $1-5 \times 10^{5} \mathrm{CFU} / \mathrm{mL}$, and $100 \mu \mathrm{L}$ of this inoculum was then added to wells containing $100 \mu \mathrm{L}$ of the compound solution (see above) to obtain a final inoculum of $0.5-2.5 \times 10^{5} \mathrm{CFU} / \mathrm{mL}$. The plates included growth control wells (inoculated in compound-free medium) and sterile (uninoculated) wells. The plate was incubated at $35^{\circ} \mathrm{C}$ for $24 \mathrm{~h}$, then the absorbance at $530 \mathrm{~nm}$ was measured using a microplate reader. The MICs were defined as the lowest concentration of antifungal compounds, at which there was no visible growth of the indicator yeast.

Determination of MICs of the isolated compounds against the filamentous fungi was performed as recommended in the EUCAST definitive document E.DEF 9.3 [129]. For the filamentous fungi, the microdilution was performed as described for the yeast, with an exception for the preparation of the inoculum. Fungi were grown on PDA at $28{ }^{\circ} \mathrm{C}$ for 5 days, and the fungal colonies were covered with $10 \mathrm{~mL}$ distilled water supplemented with $0.1 \%$ Tween 20 , and suspensions were made by scraping the surface with a sterile loop. Heavy particles in the suspension were allowed to settle for 15 to $20 \mathrm{~min}$ at room temperature. The suspension in the upper clear phase was transferred to sterile tubes and homogenized by vortexing for $15 \mathrm{~s}$. The suspension was filtered using Whatman filter paper no. 1 with a pore size of $11 \mu \mathrm{m}$ to remove large hyphal fragments. The optical density of the suspensions was recorded at $530 \mathrm{~nm}$ and then adjusted to transmittance of 80 to $85 \%$. The number of colony-forming units was quantified by plating $100 \mu \mathrm{L}$ of suspension on PDA and counting the colonies after incubating at $28^{\circ} \mathrm{C}$ for 5 days. The inoculum concentrations used ranged from 2 to $5 \times 10^{6} \mathrm{CFU} / \mathrm{mL}$. Each suspension was diluted (1:10) with sterile distilled water to obtain the working inoculum concentration of 2 to $5 \times 10^{5} \mathrm{CFU} / \mathrm{mL}$. An aliquot of $100 \mu \mathrm{L}$ of this inoculum was then added to wells containing $100 \mu \mathrm{L}$ of the compound solution (see above) to obtain a final inoculum of $1-2.5 \times 10^{5} \mathrm{CFU} / \mathrm{mL}$. The plates included growth control wells (inoculated in compound-free medium) and sterile (uninoculated) wells. The plate was incubated at $28^{\circ} \mathrm{C}$ for $48 \mathrm{~h}$, and MICs of the antifungal compounds were determined visually as the lowest concentration, at which there was no visible growth of the fungi. 
The antibiotics ampicillin, kanamycin, tetracycline, and miconazole were used as positive controls.

\section{Conclusions}

This study yielded cultivable bacteria from 18 Vietnamese sponge species and represented four bacterial phyla and 55 genera. The cultivable bacteria were predominantly members of the genera Bacillus, Pseudovibrio, Ruegeria, Vibrio, and Streptomyces. A big gap was observed between bacterial communities detected by cultivation-dependent and cultivation-independent approaches. Nevertheless, antimicrobial assays showed that 90 cultivable bacteria in this study exhibited antimicrobial activity against a large number of indicator microorganisms. From Bacillus sp. M1_CRV_171, the isolated strain with the most versatile antimicrobial activity, four known compounds with antimicrobial activity against a wide spectrum of indicator microorganisms were isolated: the cyclic dipeptide, cyclo(L-pro-L-tyr) and three macrolactins. Although these results confirm that many sponge-associated bacterial isolates have antimicrobial activity, they also stress the risks of rediscovery of compounds based on isolates obtained through traditional techniques. Therefore, the uncultivated majority of the bacteria should be targeted to get access to the full arsenal of bioactive molecules from sponges.

Supplementary Materials: The following are available online at https:/ /www.mdpi.com/article/10

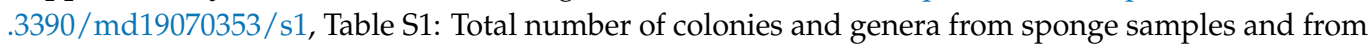
media, Table S2: Betadisper and Adonis analyses of cultivable bacteria isolated from different culture media types, Table S3: Alpha diversity indexes of cultivable bacteria isolated from culture media, Table S4: Kruskal-Wallis chi-squared of alpha diversity indexes of cultivable bacteria isolated from culture media; Table S5: List of isolated strains from sponges; Tables S6-S9: ${ }^{1} \mathrm{H}$ and ${ }^{13} \mathrm{C}$ NMR data of the isolated compounds, Figures S1-S20: Spectra of the isolated compounds, Figures S21-S33: Effects of the isolated compounds on the indicator microorganisms.

Author Contributions: Conceptualization, T.T.H.D., N.T.K.C., P.V.C., H.S. and D.S.; data curation, T.T.H.D.; formal analysis, T.T.H.D.; funding acquisition, N.T.K.C. and D.S.; investigation, T.T.H.D.; methodology, T.T.H.D.; project administration, N.T.K.C. and D.S.; supervision, N.T.K.C. and H.S.; validation, T.T.H.D. and D.S.; visualization, T.T.H.D.; writing—original draft, T.T.H.D.; writingreview and editing, T.T.H.D., N.T.K.C., P.V.C., H.S. and D.S. All authors have read and agreed to the published version of the manuscript.

Funding: This research was funded by the Vietnam Ministry of Science and Technology, grant number ĐTĐLCN.17/14; BE-Basic Foundation-FES grant from the Dutch Ministry of Economic Affairs, grant number: F07.003.06; and MC-ITN-BluePharmTrain funded through the European Union Programme FP7/2007-2013/ under REA grant agreement $n^{\circ} 607786$.

Institutional Review Board Statement: Not applicable.

Informed Consent Statement: Not applicable.

Data Availability Statement: The $16 \mathrm{~S}$ rRNA gene sequences of isolates are available in the NCBI database under accession numbers: MN703812-MN704271.

Conflicts of Interest: The authors declare no conflict of interest.

\section{References}

1. Collignon, P.; Beggs, J.J. Socioeconomic Enablers for Contagion: Factors Impelling the Antimicrobial Resistance Epidemic. Antibiotics 2019, 8, 86. [CrossRef]

2. Malik, B.; Bhattacharyya, S. Antibiotic drug-resistance as a complex system driven by socio-economic growth and antibiotic misuse. Sci. Rep. 2019, 9, 9788. [CrossRef] [PubMed]

3. Saleem, Z.; Saeed, H.; Hassali, M.A.; Godman, B.; Asif, U.; Yousaf, M.; Ahmed, Z.; Riaz, H.; Raza, S.A. Pattern of inappropriate antibiotic use among hospitalized patients in Pakistan: A longitudinal surveillance and implications. Antimicrob. Resist. Infect. Control. 2019, 8, 188. [CrossRef] [PubMed]

4. Manyi-Loh, C.; Mamphweli, S.; Meyer, E.; Okoh, A. Antibiotic Use in Agriculture and Its Consequential Resistance in Environmental Sources: Potential Public Health Implications. Molecules 2018, 23, 795. [CrossRef] [PubMed] 
5. Cantón, R.; Horcajada, J.P.; Oliver, A.; Garbajosa, P.R.; Vila, J. Inappropriate use of antibiotics in hospitals: The complex relationship between antibiotic use and antimicrobial resistance. Enferm. Infecc. Microbiol. Clínica 2013, 31, 3-11. [CrossRef]

6. O'Neill, J. Antimicrobial Resistance: Tackling a crisis for the health and wealth of nations. In Review on Antimicrobial Resistance: Chaired by Jim O'Neill, 2014; Review on AMR: London, UK, 2014.

7. Taylor, P.L.; Wright, G.D. Novel approaches to discovery of antibacterial agents. Anim. Health Res. Rev. 2008, 9, 237-246. [CrossRef] [PubMed]

8. Projan, S.J. Why is big Pharma getting out of antibacterial drug discovery? Curr. Opin. Microbiol. 2003, 6, 427-430. [CrossRef]

9. Kunakom, S.; Eustáquio, A.S. Natural Products and Synthetic Biology: Where We Are and Where We Need to Go. mSystems 2019, 4, e00113-19. [CrossRef]

10. Breitling, R.; Takano, E. Synthetic Biology of Natural Products. Cold Spring Harb. Perspect Biol. 2016, 8, a023994. [CrossRef]

11. Hughes, C.C.; Fenical, W. Antibacterials from the sea. Chemistry 2010, 16, 12512-12525. [CrossRef]

12. Montaser, R.; Luesch, H. Marine natural products: A new wave of drugs? Future Med. Chem. 2011, 3, 1475-1489. [CrossRef]

13. Choudhary, A.; Naughton, L.M.; Montánchez, I.; Dobson, A.D.W.; Rai, D.K. Current Status and Future Prospects of Marine Natural Products (MNPs) as Antimicrobials. Mar. Drugs 2017, 15, 272. [CrossRef]

14. Mehbub, F.M.; Lei, J.; Franco, C.; Zhang, W. Marine Sponge Derived Natural Products between 2001 and 2010 : Trends and Opportunities for Discovery of Bioactives. Mar. Drugs 2014, 12, 4539-4577. [CrossRef]

15. Carroll, A.R.; Copp, B.R.; Davis, R.A.; Keyzers, R.A.; Prinsep, M.R. Marine natural products. Nat. Prod. Rep. 2019, 36, 122-173. [CrossRef]

16. Jaspars, M.; De Pascale, D.; Andersen, J.H.; Reyes, F.; Crawford, A.D.; Ianora, A. The marine biodiscovery pipeline and ocean medicines of tomorrow. J. Mar. Biol. Assoc. UK 2016, 96, 151-158. [CrossRef]

17. Sipkema, D.; Franssen, M.C.R.; Osinga, R.; Tramper, J.; Wijffels, R.H. Marine Sponges as Pharmacy. Mar. Biotechnol. 2005, 7, 142-162. [CrossRef]

18. Proksch, P.; Edrada-Ebel, R.; Ebel, R. Drugs from the Sea-Opportunities and Obstacles. Mar. Drugs 2003, 1, 5-17. [CrossRef]

19. Wagner-Döbler, I.; Beil, W.; Lang, S.; Meiners, M.; Laatsch, H. Integrated Approach to Explore the Potential of Marine Microorganisms for the Production of Bioactive Metabolites. In Tools and Applications of Biochemical Engineering Science; Schügerl, K., Zeng, A.P., Aunins, J.G., Bader, A., Bell, W., Biebl, H., Biselli, M., Carrondo, M.J.T., Castilho, L.R., Chang, H.N., et al., Eds.; Springer: Berlin/Heidelberg, Germany, 2002; pp. 207-238.

20. Thoms, C.; Schupp, P. Biotechnological Potential of Marine Sponges and their Associated Bacteria as Producers of New Pharmaceuticals (Part II). J. Int. Biotechnol. Law 2005, 2, 257. [CrossRef]

21. Taylor, M.W.; Radax, R.; Steger, D.; Wagner, M. Sponge-Associated Microorganisms: Evolution, Ecology, and Biotechnological Potential. Microbiol. Mol. Biol. Rev. 2007, 71, 295-347. [CrossRef]

22. Fuerst, J.A. Diversity and biotechnological potential of microorganisms associated with marine sponges. Appl. Microbiol. Biotechnol. 2014, 98, 7331-7347. [CrossRef] [PubMed]

23. Newman, D.J.; Hill, R.T. New drugs from marine microbes: The tide is turning. J. Ind. Microbiol. Biotechnol. 2006, 33, 539-544. [CrossRef]

24. Schmidt, E.W.; Bewley, C.A.; Faulkner, D.J. Theopalauamide, a Bicyclic Glycopeptide from Filamentous Bacterial Symbionts of the Lithistid Sponge Theonella swinhoei from Palau and Mozambique. J. Org. Chem. 1998, 63, 1254-1258. [CrossRef]

25. Santos-Gandelman, J.; Giambiagi-deMarval, M.; Oelemann, W.; Laport, M. Biotechnological Potential of Sponge-Associated Bacteria. Curr. Pharm. Biotechnol. 2014, 15, 143-155. [CrossRef] [PubMed]

26. Laport, M.S.; Santos, O.C.S.; Muricy, G. Marine Sponges: Potential Sources of New Antimicrobial Drugs. Curr. Pharm. Biotechnol. 2009, 10, 86-105. [CrossRef]

27. Indraningrat, A.A.; Smidt, H.; Sipkema, D. Bioprospecting Sponge-Associated Microbes for Antimicrobial Compounds. Mar. Drugs 2016, 14, 87. [CrossRef]

28. Dat, T.T.H.; Steinert, G.; Thi Kim Cuc, N.; Smidt, H.; Sipkema, D. Archaeal and bacterial diversity and community composition from 18 phylogenetically divergent sponge species in Vietnam. Peer] 2018, 6, e4970. [CrossRef] [PubMed]

29. Wattana-Amorn, P.; Charoenwongsa, W.; Williams, C.; Crump, M.P.; Apichaisataienchote, B. Antibacterial activity of cyclo(LPro-L-Tyr) and cyclo(D-Pro-L-Tyr) from Streptomyces sp. strain 22-4 against phytopathogenic bacteria. Nat. Prod. Res. 2016, 30, 1980-1983. [CrossRef]

30. Lee, S.-J.; Cho, J.-Y.; Cho, J.-I.; Moon, J.-H.; Park, K.D.; Lee, Y.J.; Park, K.-H. Isolation and Characterization of Antimicrobial Substance Macrolactin A Produced from Bacillus amyloliquefaciens CHO104 Isolated from Soil. J. Microbiol. Biotechnol. 2004, 14, 525-531.

31. Romero-Tabarez, M.; Jansen, R.; Sylla, M.; Lünsdorf, H.; Häussler, S.; Santosa, D.A.; Timmis, K.N.; Molinari, G. 7-O-malonyl macrolactin A, a new macrolactin antibiotic from Bacillus subtilis active against methicillin-resistant Staphylococcus aureus, vancomycin-resistant enterococci, and a small-colony variant of Burkholderia cepacia. Antimicrob. Agents Chemother. 2006, 50, 1701-1709. [CrossRef]

32. Nagao, T.; Adachi, K.; Sakai, M.; Nishijima, M.; Sano, H. Novel Macrolactins as antibiotic lactones from a marine bacterium. J. Antibiot. 2001, 54, 333-339. [CrossRef] 
33. Mondol, M.A.M.; Tareq, F.S.; Kim, J.H.; Lee, M.A.; Lee, H.-S.; Lee, Y.-J.; Lee, J.S.; Shin, H.J. Cyclic Ether-Containing Macrolactins, Antimicrobial 24-Membered Isomeric Macrolactones from a Marine Bacillus sp. J. Nat. Prod. 2011, 74, 2582-2587. [CrossRef] [PubMed]

34. Li, C.Q.; Liu, W.C.; Zhu, P.; Yang, J.L.; Cheng, K.D. Phylogenetic diversity of bacteria associated with the marine sponge Gelliodes carnosa collected from the Hainan Island coastal waters of the South China Sea. Microb. Ecol. 2011, 62, 800-812. [CrossRef] [PubMed]

35. Sipkema, D.; Schippers, K.; Maalcke, W.J.; Yang, Y.; Salim, S.; Blanch, H.W. Multiple Approaches to Enhance the Cultivability of Bacteria Associated with the Marine Sponge Haliclona (gellius) sp. Appl. Environ. Microbiol. 2011, 77, 2130-2140. [CrossRef]

36. Montalvo, N.F.; Davis, J.; Vicente, J.; Pittiglio, R.; Ravel, J.; Hill, R.T. Integration of culture-based and molecular analysis of a complex sponge-associated bacterial community. PLoS ONE 2014, 9, e90517. [CrossRef]

37. Hardoim, C.C.P.; Costa, R. Microbial Communities and Bioactive Compounds in Marine Sponges of the Family Irciniidae-A Review. Mar. Drugs 2014, 12, 5089-5122. [CrossRef] [PubMed]

38. Versluis, D.; McPherson, K.; van Passel, M.W.J.; Smidt, H.; Sipkema, D. Recovery of Previously Uncultured Bacterial Genera from Three Mediterranean Sponges. Mar. Biotechnol. 2017, 19, 454-468. [CrossRef]

39. Slaby, B.M.; Hackl, T.; Horn, H.; Bayer, K.; Hentschel, U. Metagenomic binning of a marine sponge microbiome reveals unity in defense but metabolic specialization. ISME J. 2017, 11, 2465-2478. [CrossRef] [PubMed]

40. Taylor, J.A.; Palladino, G.; Wemheuer, B.; Steinert, G.; Sipkema, D.; Williams, T.J.; Thomas, T. Phylogeny resolved, metabolism revealed: Functional radiation within a widespread and divergent clade of sponge symbionts. ISME J. 2021, 15, 503-519. [CrossRef]

41. Esteves, A.I.; Amer, N.; Nguyen, M.; Thomas, T. Sample Processing Impacts the Viability and Cultivability of the Sponge Microbiome. Front. Microbiol. 2016, 7, 499. [CrossRef]

42. Steinert, G.; Whitfield, S.; Taylor, M.W.; Thoms, C.; Schupp, P.J. Application of Diffusion Growth Chambers for the Cultivation of Marine Sponge-Associated Bacteria. Mar. Biotechnol. 2014, 16, 594-603. [CrossRef]

43. Webster, N.S.; Hill, R.T. The culturable microbial community of the Great Barrier Reef sponge Rhopaloeides odorabile is dominated by an alpha-protebacterium. Mar. Biol. 2001, 138, 843-851. [CrossRef]

44. O'Halloran, J.A.; Barbosa, T.M.; Morrissey, J.P.; Kennedy, J.; O'Gara, F.; Dobson, A.D.W. Diversity and antimicrobial activity of Pseudovibrio spp. from Irish marine sponges. J. Appl. Microbiol. 2011, 110, 1495-1508. [CrossRef]

45. Enticknap, J.J.; Kelly, M.; Peraud, O.; Hill, R.T. Characterization of a culturable alphaproteobacterial symbiont common to many marine sponges and evidence for vertical transmission via sponge larvae. Appl. Environ. Microbiol. 2006, 72, 3724-3732. [CrossRef] [PubMed]

46. Hentschel, U.; Schmid, M.; Wagner, M.; Fieseler, L.; Gernert, C.; Hacker, J. Isolation and phylogenetic analysis of bacteria with antimicrobial activities from the Mediterranean sponges Aplysina aerophoba and Aplysina cavernicola. FEMS Microbiol. Ecol. 2001, 35, 305-312. [CrossRef] [PubMed]

47. Muscholl-Silberhorn, A.; Thiel, V.; Imhoff, J.F. Abundance and bioactivity of cultured sponge-associated bacteria from the Mediterranean sea. Microb. Ecol. 2008, 55, 94-106. [CrossRef]

48. Garland, J.L.; Cook, K.L.; Adams, J.L.; Kerkhof, L. Culturability as an Indicator of Succession in Microbial Communities. Microb. Ecol. 2001, 42, 150-158. [CrossRef] [PubMed]

49. Hernández-González, I.L.; Moreno-Hagelsieb, G.; Olmedo-Álvarez, G. Environmentally-driven gene content convergence and the Bacillus phylogeny. BMC Evol. Biol. 2018, 18, 148. [CrossRef]

50. Ian, E.; Malko, D.B.; Sekurova, O.N.; Bredholt, H.; Rückert, C.; Borisova, M.E.; Albersmeier, A.; Kalinowski, J.; Gelfand, M.S.; Zotchev, S.B. Genomics of Sponge-Associated Streptomyces spp. Closely Related to Streptomyces albus J1074: Insights into Marine Adaptation and Secondary Metabolite Biosynthesis Potential. PLoS ONE 2014, 9, e96719. [CrossRef]

51. Alex, A.; Antunes, A. Whole Genome Sequencing of the Symbiont Pseudovibrio sp. from the Intertidal Marine Sponge Polymastia penicillus Revealed a Gene Repertoire for Host-Switching Permissive Lifestyle. Genome Biol. Evol. 2015, 7, 3022-3032. [CrossRef]

52. Alex, A.; Antunes, A. Genus-wide comparison of Pseudovibrio bacterial genomes reveal diverse adaptations to different marine invertebrate hosts. PLoS ONE 2018, 13, e0194368. [CrossRef]

53. Belbahri, L.; Bouket, A.C.; Rekik, I.; Alenezi, F.N.; Vallat, A.; Luptakova, L.; Petrovova, E.; Oszako, T.; Cherrad, S.; Vacher, S.; et al. Comparative Genomics of Bacillus amyloliquefaciens Strains Reveals a Core Genome with Traits for Habitat Adaptation and a Secondary Metabolites Rich Accessory Genome. Front. Microbiol. 2017, 8, 1438. [CrossRef]

54. Versluis, D.; Nijsse, B.; Naim, M.A.; Koehorst, J.J.; Wiese, J.; Imhoff, J.F.; Schaap, P.J.; van Passel, M.W.J.; Smidt, H.; Sipkema, D. Comparative Genomics Highlights Symbiotic Capacities and High Metabolic Flexibility of the Marine Genus Pseudovibrio. Genome Biol. Evol. 2018, 10, 125-142. [CrossRef] [PubMed]

55. Romano, S. Ecology and Biotechnological Potential of Bacteria Belonging to the Genus Pseudovibrio. Appl. Environ. Microbiol. 2018, 84, e02516-17. [CrossRef] [PubMed]

56. Steil, L.; Hoffmann, T.; Budde, I.; Völker, U.; Bremer, E. Genome-Wide Transcriptional Profiling Analysis of Adaptation of Bacillus subtilis to High Salinity. J. Bacteriol. 2003, 185, 6358. [CrossRef]

57. Tian, X.; Zhang, Z.; Yang, T.; Chen, M.; Li, J.; Chen, F.; Yang, J.; Li, W.; Zhang, B.; Zhang, Z.; et al. Comparative Genomics Analysis of Streptomyces Species Reveals Their Adaptation to the Marine Environment and Their Diversity at the Genomic Level. Front. Microbiol. 2016, 7, 998. [CrossRef] 
58. Brito, P.H.; Chevreux, B.; Serra, C.R.; Schyns, G.; Henriques, A.O.; Pereira-Leal, J.B. Genetic Competence Drives Genome Diversity in Bacillus subtilis. Genome Biol. Evol. 2018, 10, 108-124. [CrossRef]

59. Lin, H.; Yu, M.; Wang, X.; Zhang, X.-H. Comparative genomic analysis reveals the evolution and environmental adaptation strategies of vibrios. BMC Genom. 2018, 19, 1-14. [CrossRef] [PubMed]

60. Bondarev, V.; Richter, M.; Romano, S.; Piel, J.; Schwedt, A.; Schulz-Vogt, H.N. The genus Pseudovibrio contains metabolically versatile bacteria adapted for symbiosis. Environ. Microbiol. 2013, 15, 2095-2113. [CrossRef] [PubMed]

61. Díez-Vives, C.; Esteves, A.I.S.; Costa, R.; Nielsen, S.; Thomas, T. Detecting signatures of a sponge-associated lifestyle in bacterial genomes. Environ. Microbiol. Rep. 2018, 10, 433-443. [CrossRef]

62. Helber, S.B.; Hoeijmakers, D.J.J.; Muhando, C.A.; Rohde, S.; Schupp, P.J. Sponge chemical defenses are a possible mechanism for increasing sponge abundance on reefs in Zanzibar. PLoS ONE 2018, 13, e0197617. [CrossRef]

63. Pawlik, J.R. The Chemical Ecology of Sponges on Caribbean Reefs: Natural Products Shape Natural Systems. BioScience 2011, 61, 888-898. [CrossRef]

64. Rohde, S.; Nietzer, S.; Schupp, P.J. Prevalence and Mechanisms of Dynamic Chemical Defenses in Tropical Sponges. PLoS ONE 2015, 10, e0132236. [CrossRef]

65. Flowers, A.E.; Garson, M.J.; Webb, R.I.; Dumdei, E.J.; Charan, R.D. Cellular origin of chlorinated diketopiperazines in the dictyoceratid sponge Dysidea herbacea (Keller). Cell Tissue Res. 1998, 292, 597-607. [CrossRef]

66. Piel, J.; Hui, D.; Wen, G.; Butzke, D.; Platzer, M.; Fusetani, N.; Matsunaga, S. Antitumor polyketide biosynthesis by an uncultivated bacterial symbiont of the marine sponge Theonella swinhoei. Proc. Natl. Acad. Sci. USA 2004, 101, 16222-16227. [CrossRef]

67. Faulkner, D.J.; Harper, M.K.; Haygood, M.G.; Salomon, C.E.; Schmidt, E.W. Symbiotic bacteria in sponges: Sources of bioactive substances. In Drugs from the Sea; Karger Publishers: Basel, Switzerland, 2000; pp. 107-119.

68. Haygood, M.G.; Schmidt, E.W.; Davidson, S.K.; Faulkner, D.J. Microbial symbionts of marine invertebrates: Opportunities for microbial biotechnology. J. Mol. Microbiol. Biotechnol. 1999, 1, 33-43. [PubMed]

69. Hildebrand, M.; Waggoner, L.E.; Lim, G.E.; Sharp, K.H.; Ridley, C.P.; Haygood, M.G. Approaches to identify, clone, and express symbiont bioactive metabolite genes. Nat. Prod. Rep. 2004, 21, 122-142. [CrossRef]

70. Page, M.G.P. The role of the outer membrane of gram-negative bacteria in antibiotic resistance: Ajax' shield or Achilles' heel? In Antibiotic Resistance. Handbook of Experimental Pharmacology; Springer: Berlin/Heidelberg, Germany, 2012; Volume 211, pp. 67-86.

71. Naughton, L.M.; Romano, S.; O'Gara, F.; Dobson, A.D.W. Identification of Secondary Metabolite Gene Clusters in the Pseudovibrio Genus Reveals Encouraging Biosynthetic Potential toward the Production of Novel Bioactive Compounds. Front. Microbiol. 2017, 8, 1494. [CrossRef]

72. Xu, L.; Ye, K.-X.; Dai, W.-H.; Sun, C.; Xu, L.-H.; Han, B.-N. Comparative Genomic Insights into Secondary Metabolism Biosynthetic Gene Cluster Distributions of Marine Streptomyces. Mar. Drugs 2019, 17, 498. [CrossRef] [PubMed]

73. Harwood, C.R.; Mouillon, J.-M.; Pohl, S.; Arnau, J. Secondary metabolite production and the safety of industrially important members of the Bacillus subtilis group. FEMS Microbiol. Rev. 2018, 42, 721-738. [CrossRef]

74. Mondol, M.A.M.; Shin, H.J.; Islam, M.T. Diversity of secondary metabolites from marine Bacillus species: Chemistry and biological activity. Mar. Drugs 2013, 11, 2846-2872. [CrossRef] [PubMed]

75. Caulier, S.; Nannan, C.; Gillis, A.; Licciardi, F.; Bragard, C.; Mahillon, J. Overview of the Antimicrobial Compounds Produced by Members of the Bacillus subtilis Group. Front. Microbiol. 2019, 10, 302. [CrossRef] [PubMed]

76. Sumi, C.D.; Yang, B.W.; Yeo, I.-C.; Hahm, Y.T. Antimicrobial peptides of the genus Bacillus: A new era for antibiotics. Can. J. Microbiol. 2014, 61, 93-103. [CrossRef]

77. Grubbs, K.J.; Bleich, R.M.; Santa Maria, K.C.; Allen, S.E.; Farag, S.; AgBiome, T.; Shank, E.A.; Bowers, A.A. Large-Scale Bioinformatics Analysis of Bacillus Genomes Uncovers Conserved Roles of Natural Products in Bacterial Physiology. mSystems 2017, 2, e00040-17. [CrossRef]

78. Stein, T. Bacillus subtilis antibiotics: Structures, syntheses and specific functions. Mol. Microbiol. 2005, 56, 845-857. [CrossRef] [PubMed]

79. Kunst, F.; Ogasawara, N.; Moszer, I.; Albertini, A.M.; Alloni, G.; Azevedo, V.; Bertero, M.G.; Bessières, P.; Bolotin, A.; Borchert, S.; et al. The complete genome sequence of the Gram-positive bacterium Bacillus subtilis. Nature 1997, 390, 249-256. [CrossRef]

80. Chen, X.H.; Koumoutsi, A.; Scholz, R.; Eisenreich, A.; Schneider, K.; Heinemeyer, I.; Morgenstern, B.; Voss, B.; Hess, W.R.; Reva, O.; et al. Comparative analysis of the complete genome sequence of the plant growth-promoting bacterium Bacillus amyloliquefaciens FZB42. Nat. Biotechnol. 2007, 25, 1007-1014. [CrossRef] [PubMed]

81. De Rosa, S.; Mitova, M.; Tommonaro, G. Marine bacteria associated with sponge as source of cyclic peptides. Biomol. Eng. 2003, 20,311-316. [CrossRef]

82. Mitova, M.; Tommonaro, G.; Hentschel, U.; Müller, W.E.G.; De Rosa, S. Exocellular Cyclic Dipeptides from a Ruegeria Strain Associated with Cell Cultures of Suberites domuncula. Mar. Biotechnol. 2004, 6, 95-103. [CrossRef] [PubMed]

83. Huayue, L.; Byung Cheol, L.; Tae Sung, K.; Kyung Sook, B.; Jongki, H.; Sang Ho, C.; Baoquan, B.; Jee Hyung, J. Bioactive Cyclic Dipeptides from a Marine Sponge-Associated Bacterium, Psychrobacter sp. Biomol. Ther. 2008, 16, 356-363.

84. Sawangwong, P.; Wattanadilok, R.; Kijjoa, A.; Silva, A.M.S.; Eaton, G.; Herz, W. Secondary metabolites from a marine sponge Cliona patera. Biochem. Syst. Ecol. 2008, 36, 493-496. [CrossRef]

85. Abbamondi, G.R.; De Rosa, S.; Iodice, C.; Tommonaro, G. Cyclic Dipeptides Produced by Marine Sponge-Associated Bacteria as Quorum Sensing Signals. Nat. Prod. Commun. 2014, 9. [CrossRef] 
86. Jayatilake, G.S.; Thornton, M.P.; Leonard, A.C.; Grimwade, J.E.; Baker, B.J. Metabolites from an Antarctic Sponge-Associated Bacterium, Pseudomonas aeruginosa. J. Nat. Prod. 1996, 59, 293-296. [CrossRef] [PubMed]

87. Kumar, S.N.; Lankalapalli, R.S.; Kumar, B.S.D. In Vitro Antibacterial Screening of Six Proline-Based Cyclic Dipeptides in Combination with $\beta$-Lactam Antibiotics Against Medically Important Bacteria. Appl. Biochem. Biotechnol. 2014, 173, 116-128. [CrossRef]

88. Smaoui, S.; Mathieu, F.; Elleuch, L.; Coppel, Y.; Merlina, G.; Karray-Rebai, I.; Mellouli, L. Taxonomy, purification and chemical characterization of four bioactive compounds from new Streptomyces sp. TN256 strain. World J. Microbiol. Biotechnol. 2012, 28, 793-804. [CrossRef] [PubMed]

89. Sansinenea, E.; Salazar, F.; Jiménez, J.; Mendoza, Á.; Ortiz, A. Diketopiperazines derivatives isolated from Bacillus thuringiensis and Bacillus endophyticus, establishment of their configuration by X-ray and their synthesis. Tetrahedron Lett. 2016, 57, $2604-2607$. [CrossRef]

90. Yonezawa, K.; Yamada, K.; Kouno, I. New Diketopiperazine Derivatives Isolated from Sea Urchin-Derived Bacillus sp. Chem. Pharm. Bull. 2011, 59, 106-108. [CrossRef] [PubMed]

91. Cimmino, A.; Puopolo, G.; Perazzolli, M.; Andolfi, A.; Melck, D.; Pertot, I.; Evidente, A. Cyclo(L-pro-L-tyr), The Fungicide Isolated From Lysobacter Capsici AZ78: A Structure-Activity Relationship Study. Chem. Heterocycl. Compd. 2014, 50, 290-295. [CrossRef]

92. Puopolo, G.; Cimmino, A.; Palmieri, M.C.; Giovannini, O.; Evidente, A.; Pertot, I. Lysobacter capsici AZ78 produces cyclo(1-Pro-1Tyr), a 2,5-diketopiperazine with toxic activity against sporangia of Phytophthora infestans and Plasmopara viticola. J. Appl. Microbiol. 2014, 117, 1168-1180. [CrossRef]

93. Degrassi, G.; Aguilar, C.; Bosco, M.; Zahariev, S.; Pongor, S.; Venturi, V. Plant Growth-Promoting Pseudomonas putida WCS358 Produces and Secretes Four Cyclic Dipeptides: Cross-Talk with Quorum Sensing Bacterial Sensors. Curr. Microbiol. 2002, 45, 250-254. [CrossRef]

94. González, J.E.; Keshavan, N.D. Messing with Bacterial Quorum Sensing. Microbiol. Mol. Biol. Rev. 2006, 70, 859. [CrossRef] [PubMed]

95. Ortiz-Castro, R.; Díaz-Pérez, C.; Martínez-Trujillo, M.; del Río, R.E.; Campos-García, J.; López-Bucio, J. Transkingdom signaling based on bacterial cyclodipeptides with auxin activity in plants. Proc. Natl. Acad. Sci. USA 2011, 108, 7253. [CrossRef] [PubMed]

96. Holden, M.T.G.; Ram Chhabra, S.; De Nys, R.; Stead, P.; Bainton, N.J.; Hill, P.J.; Manefield, M.; Kumar, N.; Labatte, M.; England, D.; et al. Quorum-sensing cross talk: Isolation and chemical characterization of cyclic dipeptides from Pseudomonas aeruginosa and other Gram-negative bacteria. Mol. Microbiol. 1999, 33, 1254-1266. [CrossRef]

97. Wang, J.-H.; Quan, C.-S.; Qi, X.-H.; Li, X.; Fan, S.-D. Determination of diketopiperazines of Burkholderia cepacia CF-66 by gas chromatography-mass spectrometry. Anal. Bioanal. Chem. 2010, 396, 1773-1779. [CrossRef] [PubMed]

98. Ryan, R.P.; Dow, J.M. Diffusible signals and interspecies communication in bacteria. Microbiology 2008, 154, 1845-1858. [CrossRef] [PubMed]

99. Li, J.; Wang, W.; Xu, S.X.; Magarvey, N.A.; McCormick, J.K. Lactobacillus reuteri-produced cyclic dipeptides quench agr-mediated expression of toxic shock syndrome toxin-1 in staphylococci. Proc. Natl. Acad. Sci. USA 2011, 108, 3360. [CrossRef]

100. Teasdale, M.E.; Donovan, K.A.; Forschner-Dancause, S.R.; Rowley, D.C. Gram-Positive Marine Bacteria as a Potential Resource for the Discovery of Quorum Sensing Inhibitors. Mar. Biotechnol. 2011, 13, 722-732. [CrossRef]

101. Fuqua, C.; Parsek, M.R.; Greenberg, E.P. Regulation of Gene Expression by Cell-to-Cell Communication: Acyl-Homoserine Lactone Quorum Sensing. Annu. Rev. Genet. 2001, 35, 439-468. [CrossRef]

102. Smith, D.; Wang, J.-H.; Swatton, J.E.; Davenport, P.; Price, B.; Mikkelsen, H.; Stickland, H.; Nishikawa, K.; Gardiol, N.; Spring, D.R.; et al. Variations on a Theme: Diverse N-Acyl Homoserine Lactone-Mediated Quorum Sensing Mechanisms in Gram-Negative Bacteria. Sci. Prog. 2006, 89, 167-211. [CrossRef] [PubMed]

103. Taylor, M.W.; Schupp, P.J.; Baillie, H.J.; Charlton, T.S.; de Nys, R.; Kjelleberg, S.; Steinberg, P.D. Evidence for acyl homoserine lactone signal production in bacteria associated with marine sponges. Appl. Environ. Microbiol. 2004, 70, 4387-4389. [CrossRef]

104. Bin Saidin, J.; Abd Wahid, M.E.; Le Pennec, G. Characterization of the in vitro production of N-acyl homoserine lactones by cultivable bacteria inhabiting the sponge Suberites domuncula. J. Mar. Biol. Assoc. UK 2016, 97, 119-127. [CrossRef]

105. Bose, U.; Ortori, C.A.; Sarmad, S.; Barrett, D.A.; Hewavitharana, A.K.; Hodson, M.P.; Fuerst, J.A.; Shaw, P.N. Production of N-acyl homoserine lactones by the sponge-associated marine actinobacteria Salinispora arenicola and Salinispora pacifica. FEMS Microbiol. Lett. 2017, 364, fnx002. [CrossRef]

106. Britstein, M.; Saurav, K.; Teta, R.; Sala, G.D.; Bar-Shalom, R.; Stoppelli, N.; Zoccarato, L.; Costantino, V.; Steindler, L. Identification and chemical characterization of $\mathrm{N}$-acyl-homoserine lactone quorum sensing signals across sponge species and time. FEMS Microbiol. Ecol. 2017, 94, fix182. [CrossRef]

107. Kanoh, S.; Rubin, B.K. Mechanisms of action and clinical application of macrolides as immunomodulatory medications. Clin. Microbiol. Rev. 2010, 23, 590-615. [CrossRef]

108. Karpiński, T.M. Marine Macrolides with Antibacterial and/or Antifungal Activity. Mar. Drugs 2019, 17, 241. [CrossRef]

109. Tareq, F.S.; Kim, J.H.; Lee, M.A.; Lee, H.-S.; Lee, J.-S.; Lee, Y.-J.; Shin, H.J. Antimicrobial Gageomacrolactins Characterized from the Fermentation of the Marine-Derived Bacterium Bacillus subtilis under Optimum Growth Conditions. J. Agric. Food Chem. 2013, 61, 3428-3434. [CrossRef] 
110. Lu, X.L.; Xu, Q.Z.; Shen, Y.H.; Liu, X.Y.; Jiao, B.H.; Zhang, W.D.; Ni, K.Y. Macrolactin S, a novel macrolactin antibiotic from marine Bacillus sp. Nat. Prod. Res. 2008, 22, 342-347. [CrossRef]

111. Yoo, J.-S.; Zheng, C.-J.; Lee, S.; Kwak, J.-H.; Kim, W.-G. Macrolactin N, a new peptide deformylase inhibitor produced by Bacillus subtilis. Bioorganic Med. Chem. Lett. 2006, 16, 4889-4892. [CrossRef]

112. Gao, C.; Chen, X.; Yu, L.; Jiang, L.; Pan, D.; Jiang, S.; Gan, Y.; Liu, Y.; Yi, X. New 24-Membered Macrolactins Isolated from Marine Bacteria Bacillus siamensis as Potent Fungal Inhibitors against Sugarcane Smut. J. Agric. Food Chem. 2021, 69, 4392-4401. [CrossRef]

113. Zotchev, S.B.; Stepanchikova, A.V.; Sergeyko, A.P.; Sobolev, B.N.; Filimonov, D.A.; Poroikov, V.V. Rational Design of Macrolides by Virtual Screening of Combinatorial Libraries Generated through in Silico Manipulation of Polyketide Synthases. J. Med. Chem. 2006, 49, 2077-2087. [CrossRef]

114. Kim, D.H.; Kim, H.K.; Kim, K.M.; Kim, C.K.; Jeong, M.H.; Ko, C.Y.; Moon, K.H.; Kang, J.S. Antibacterial activities of macrolactin a and 7-O-succinyl macrolactin a from Bacillus polyfermenticus KJS-2 against vancomycin-resistant enterococci and methicillinresistant Staphylococcus aureus. Arch. Pharmacal Res. 2011, 34, 147-152. [CrossRef]

115. Li, W.; Tang, X.-X.; Yan, X.; Wu, Z.; Yi, Z.-W.; Fang, M.-J.; Su, X.; Qiu, Y.-K. A new macrolactin antibiotic from deep sea-derived bacteria Bacillus subtilis B5. Nat. Prod. Res. 2016, 30, 2777-2782. [CrossRef]

116. Weiner, R.M.; Segall, A.M.; Colwell, R.R. Characterization of a Marine Bacterium Associated with Crassostrea virginica (the Eastern Oyster). Appl. Environ. Microbiol. 1985, 49, 83-90. [CrossRef]

117. Mincer, T.J.; Jensen, P.R.; Kauffman, C.A.; Fenical, W. Widespread and persistent populations of a major new marine actinomycete taxon in ocean sediments. Appl. Environ. Microbiol. 2002, 68, 5005-5011. [CrossRef]

118. Reasoner, D.J.; Geldreich, E.E. A New Medium for the Enumeration and Subculture of Bacteria from Potable Water. Appl. Environ. Microbiol. 1985, 49, 1-7. [CrossRef]

119. Kuster, E.; William, S.T. Selection of media for isolation of streptomyces. Nature 1964, 202, 928-929. [CrossRef]

120. Olson, J.B.; Lord, C.C.; McCarthy, P.J. Improved Recoverability of Microbial Colonies from Marine Sponge Samples. Microb. Ecol. 2000, 40, 139-147. [CrossRef]

121. Lane, D.J.; Pace, B.; Olsen, G.J.; Stahl, D.A.; Sogin, M.L.; Pace, N.R. Rapid determination of $16 S$ ribosomal RNA sequences for phylogenetic analyses. Proc. Natl. Acad. Sci. USA 1985, 82, 6955. [CrossRef]

122. Lane, D.J. 16S/23S rRNA sequencing. In Nucleic Acid Techniques in Bacterial Systematics; Stackebrandt, E., Goodfellow, M., Eds.; John Wiley \& Sons: New York, NY, USA, 1991.

123. Altschul, S.F.; Gish, W.; Miller, W.; Myers, E.W.; Lipman, D.J. Basic local alignment search tool. J. Mol. Biol. 1990, 215 , 403-410. [CrossRef]

124. R Core Team. R: A Language and Environment for Statistical Computing; R Foundation for Statistical Computing: Vienna, Austria, 2016. Available online: http:/ /www.R-project.org/ (accessed on 5 December 2018).

125. Oksanen, J.; Blanchett, F.G.; Kindt, R.; Legendre, P.; Minchin, P.R.; O’Hara, R.B.; Simpson, G.L.; Solymos, P.; Stevens, M.H.M.; Wagner, H. Vegan: Community Ecology Package. R Package 2.4.0. 2016. Available online: https: / CRAN.R-project.org/package= vegan (accessed on 5 December 2018).

126. Joachimiak, M.P.; Weisman, J.L.; May, B.C.H. JColorGrid: Software for the visualization of biological measurements. BMC Bioinform. 2006, 7, 225. [CrossRef]

127. EUCAST. Determination of minimum inhibitory concentrations (MICs) of antibacterial agents by broth dilution. Clin. Microbiol. Infect. 2003, 9, ix-xv. [CrossRef]

128. Arendrup, M.C.; Guinea, J.; Cuenca-Estrell, M.; Meletiadis, J.; Mouton, J.W.; Lagrou, K.; Howard, S.J.; EUCAST-AFST. EUCAST Definitive Document E.DEF 7.3: Method for the Determination of Broth Dilution Minimum Inhibitory Concentrations of Antifungal Agents for Yeasts; EUCAST: Växjö, Sweden, 2015.

129. Arendrup, M.C.; Guinea, J.; Cuenca-Estrell, M.; Meletiadis, J.; Mouton, J.W.; Lagrou, K.; Howard, S.J.; EUCAST-AFST. EUCAST Definitive Documnet E.DEF 9.3: Method for the Determination of Broth Dilution Minimum Inhibitory Concentrations of Antifungal Agents for Conidia Forming Moulds; EUCAST: Växjö, Sweden, 2015. 